Elsevier required licence: (c) 2018. This manuscript version is made available under the CC-BY-NC-ND 4.0 license http://creativecommons.org/licenses/by-nc-nd/4.0/ 


\section{Market reaction to Non-GAAP Earnings around SEC regulation}

David Bond ${ }^{\star}$, Robert Czernkowski ${ }^{\star *}$, Yong-Suk Lee ${ }^{\star}$ and Anna Loyeung ${ }^{\star}$

\section{Abstract}

\section{May 2017}

This study examines the impact of Regulation $G$ in 2003 and the issuance of Compliance and Disclosure Interpretations (C\&DIs) in 2010 - on the reporting of non-GAAP earnings. The study finds that (i) both Regulation $G$ and C\&Dls are associated with an increase in the quality of non-GAAP earnings exclusions (i.e. the exclusions are more transitory and have less predictive power for future operating earnings); (ii) Regulation $G$ led to a decrease in the amount of total positive exclusions used to meet or beat analysts' forecasts, but C\&DIs partially reversed this result; and (iii) Regulation $G$ increases, and C\&DIs decrease, the earnings response coefficients (ERCs).

Keywords: Non-GAAP earnings; Non-GAAP exclusions; Regulation G;

C\&DIs; Analysts' forecasts; ERCs.

\footnotetext{
- The authors wish to thank the anonymous reviewer for extensive constructive feedback, and also acknowledge the input of participants in the 2016 EAA Congress in Maastricht, The Netherlands, and the 2016 AFAANZ Conference on the Gold Coast, Australia.

- University of Technology Sydney, Australia

* corresponding author: UTS Business School, University of Technology Sydney, CB08.07.99, P.O. Box 123, Broadway NSW 2007, Australia; robertcz@uts.edu.au
} 


\section{Introduction}

Over the past two decades, the reporting of non-GAAP earnings (also known as "proforma", "street", or "core" earnings) has increased dramatically (Bradshaw and Sloan, 2002; Kolev et al., 2008). In 2003, the U.S. Securities and Exchange Commission (SEC) raised concerns regarding the potential misuse of non-GAAP reporting and intervened to regulate the reporting of non-GAAP earnings by issuing Regulation $G$. The SEC also amended Item 10(e) of Regulation $S-K$ in 2003 by imposing additional disclosure requirements and restrictions on firms when non-GAAP financial measures are included in their SEC filings. Subsequently, in 2010, the SEC issued new Compliance and Disclosure Interpretations (C\&DIs). The C\&DIs relaxed the rigorous guidelines (Form 8-K Frequently Asked Questions (FAQs) on Regulation $G$ and Item 10(e) of Regulation $S-K$ without changing the current regulation. ${ }^{1}$ They also allowed SEC registrants to use extensive discretion as to how to adjust for recurring items. ${ }^{2}$

This study investigates the effects of both Regulation $G$ and C\&DIs on the quality of exclusions from non-GAAP reporting on accounting information. Specifically, the objectives of this study are to examine: (i) whether there is an association between the exclusions and future operating earnings, (ii) whether positive non-GAAP exclusions are associated with firm's meeting or slightly exceeding analysts' forecasts, and (iii) the market response to earnings announcements before and after Regulation $G$ and C\&DIs. Consistent with prior studies, high quality exclusions are defined as those that are more transitory and have less predictive power for future operating earnings (e.g. Doyle et al., 2003; Gu and Chen, 2004; Kolev et al., 2008).

The motivation for this study is two-fold. First, this study exploits two SEC interventions to investigate whether they achieved their desired outcomes. The two SEC interventions are: the SEC's implementation of Regulation $G$ in 2003, imposing additional disclosure and filing requirements on firms publicly disclosing non-GAAP earnings; and the SEC's issuance of new C\&DIs in 2010. The restrictive guidelines of Regulation $G$ are aimed at mitigating the improper use of non-GAAP reporting. Empirical findings tend to support the implementation of Regulation $G$, as it improves the quality of non-GAAP earnings exclusions and curtails opportunistic behaviour by firms (e.g. Frankel et al., 2011; Heflin and Hsu, 2008; Kolev et al., 2008). However, concerns were raised regarding the significant "administrative burden" imposed on firms that disclosed non-GAAP earnings (specifically those adjusting for recurring items) under Regulation $G$. This resulted in the SEC issuing new C\&DIs. The new C\&DIs relaxed the regulatory environment and eliminated the "administrative burden" associated with the exclusion of recurring items. ${ }^{3}$ The C\&DIs provides an interesting setting

$1 \quad$ Item 10(e) of Regulation $S-K$ applies additional and more stringent requirements to periodic reports and other documents filed with the SEC - this includes non-GAAP financial measures (Source: https://www.sec.gov/divisions/corpfin/guidance/nongaapinterp.htm). Questions 102.03 and 102.04 are examples where C\&DIs relaxed the rigorous guidelines of Item 10(e) of Regulation S-K. For example, Question 8 (Item 10(e) of Regulation S-K) previously required firms to "demonstrate the usefulness of any measure that excludes recurring items". The burden of demonstrating "usefulness" was a major hurdle that discouraged firms from disclosing non-GAAP earnings. The new C\&DIs eliminate this hurdle by giving firms flexibility in adjusting for recurring items, provided these items are not labelled as non-recurring.

3 For example, Regulation $G$ requires firms to show a reconciliation of the non-GAAP financial measure to the GAAP financial measure. Regulation $G$ also discourages firms from reporting non-GAAP measures due to the burden of having to justify the exclusion of recurring items. 
to examine whether a more relaxed environment encouraged or discouraged firms to better communicate with shareholders through non-GAAP earnings. Empirical evidence on the effectiveness of the issuance of C\&DIs is limited (the notable exception being Kyung and Weintrop, 2016).

The second motivation is to add to the debate on the disclosure of non-GAAP earnings. Extant research proposes competing theories to explain the use of non-GAAP earnings. On one hand, the information hypothesis proposes that excluding transitory items when estimating non-GAAP earnings enables managers to provide enhanced earnings measurement (Bradshaw and Sloan, 2002; Brown and Sivakumar, 2003; Doyle et al., 2003; Frankel and Roychowdhury, 2005; Kolev et al., 2008). On the other hand, the opportunism hypothesis argues that excluding certain income-decreasing components enables managers to report non-GAAP earnings metrics that exceed GAAP earnings figures (Black and Christensen, 2009; Brown et al., 2012; Doyle et al., 2003; McVay, 2006). In this study, equal weight is placed on these two hypotheses; both motives could affect managers' non-GAAP earnings disclosure practice, and it is difficult to determine which motivation is more pervasive.

Consistent with Doyle et al. (2003) and Kolev et al. (2008), this study separates nonGAAP earnings exclusions into special items (i.e. typically regarded as transitory or nonrecurring) and other exclusions. ${ }^{4}$ This study first documents that the quality of exclusions has improved following Regulation $G$ and C\&DIs (i.e. exclusions are more transitory). Specifically, the study documents that the negative association between non-GAAP exclusions (total exclusions, special items and other exclusions) and future operating performance becomes less negative post-Regulation $G$ and post-C\&DIs. Second, this study documents that the positive association between total positive exclusions and the probability of meeting or beating analysts' forecasts becomes less positive after Regulation $G$, but more positive after C\&DIs. ${ }^{5}$ Third, the market response test produces opposite results for Regulation $G$ and C\&DIs. Specifically, the coefficient on earnings surprise (ERC) increases post-Regulation $G$ but reduces post-C\&DIs, suggesting that more informative earnings are being announced after Regulation $G$, but this effect is reduced by C\&DIs. Overall, the results suggest that Regulation $G$ and C\&DIs had effects: Regulation $G$, as intended, yielded higher quality exclusions; a reduction in the amount of total positive exclusions used to meet or beat analysts' forecasts; and higher ERCs. In contrast, while the

Doyle et al. (2003) divide total exclusions into special items and other exclusions and recognize special items as one-time items, such as gains or losses on assets, merger and acquisition costs, stock-related charges, and restructuring charges, while other exclusions include recurring items such as depreciation and amortization expenses, stock-based compensation costs, R\&D expenses, as well as other adjustments including interest-related charges, tax-related costs and investment costs.

In a similar study, Heflin and Hsu (2008) find a decrease in the likelihood of meeting or beating analysts' forecasts following Regulation $G$, which is consistent with the interpretation of the findings in findings presented here. The main difference between this study and that of Heflin and Hsu (2008) is that Heflin and Hsu (2008) focus on the impact of Regulation $G$ on the probability to meet or beat analysts' forecast, whereas this study focuses on the how Regulation $G$ impacts on the use of positive exclusions to meet or beat analysts' forecasts (i.e. the interaction term between Regulation $G$ and positive exclusions). The results reported in Table 6 suggest that Regulation $G$ reduced the amount of positive exclusions used to meet or beat analysts' forecast. 
introduction of C\&DIs resulted in higher quality exclusions, they did not reduce the amount of total exclusions used to meet or beat analyst's forecasts and resulted in lower ERCs.

This study makes numerous contributions to the literature. First, this study extends the study by Kolev et al. (2008) by documenting that the quality of non-GAAP exclusions also increased post-C\&DIs, despite C\&DIs not being an actual regulation. Second, this study extends the study by Heflin and Hsu (2008) by investigating how Regulation $G$ and C\&DIs impacted on the amount of positive exclusions used to meet or beat analysts' forecasts. Third, this study extends the investigation of non-GAAP reporting - beyond consideration of how the non-GAAP announcement information maps into future earnings and analyst accuracy - to demonstrate the impact that institutional changes have on the informativeness of earnings, through ERCs. Hence, this research adds to a growing body of literature that investigates the consequences of Regulation $G$ (e.g. Heflin and Hsu, 2008; Kolev et al., 2008) and the emerging literature that investigates the consequences of C\&DIs (Kyung and Weintrop, 2016). The results reported in this study add to the disclosure regulation literature by providing empirical evidence on the economic consequences of regulations, which may curtail the frequency and quality of non-GAAP reporting.

The remainder of this study is arranged as follows. Section 2 provides an overview of Regulation $G$ and the C\&DIs, reviews previous literature on non-GAAP earnings, and develops the hypotheses. Section 3 provides a description of the sample selection and research design to test the hypotheses. The results are outlined in Section 4, and Section 5 concludes.

\section{Regulatory setting, literature review and hypotheses}

\subsection{Regulatory setting and literature review}

Non-GAAP earnings reporting became increasingly prevalent during the 1990s (Bradshaw and Sloan, 2002). Non-GAAP figures tend to be more value-relevant, on average, than GAAP earnings (Bhattacharya et al., 2003; Bradshaw and Sloan, 2002; Frankel and Roychowdhury, 2005). The rationale put forward by managers and in the business press is that the exclusions from non-GAAP earnings are regarded as being transitory and nonrecurring, non-cash, or uninformative of the firm's core operating earnings (Doyle et al., 2003; Gu and Chen, 2004). Numerous studies have found evidence supporting this perspective (i.e. the information hypothesis) of non-GAAP earnings. For instance, Lougee and Marquardt (2004) find that non-GAAP earnings help predict future profitability when a firm's GAAP earnings informativeness is low and that this firm is more likely to report nonGAAP figures. Empirical evidence also suggests that investors consider non-GAAP earnings as a more informative figure (e.g. Bradshaw and Sloan, 2002; Lougee and Marquardt, 2004).

However, it is possible for firms to use non-GAAP earnings disclosures opportunistically. Non-GAAP earnings disclosures are less regulated and therefore self-determined by corporate managers. For example, Doyle et al. (2003) find that non-GAAP earnings exclusions have predictive ability for future operating earnings and abnormal returns, which indicates that these exclusions may be recurring in the subsequent period. Furthermore, managers seem to use non-GAAP earnings financial metrics to meet or exceed analysts' forecasts (Doyle et al., 2013; Lougee and Marquardt, 2004).

On January 22, 2003, the SEC introduced Regulation $G$ to regulate the reporting of nonGAAP earnings. Regulation $G$ potentially influences both opportunism and informativeness 
of non-GAAP earnings. The reconciliation and management-description provisions of the regulations were intended to make opportunism of non-GAAP earnings reporting transparent and costly, thus enhancing the quality of the exclusions from non-GAAP earnings. Empirical evidence is consistent with this view. For example, Kolev et al. (2008) find that after Regulation $G$, the components excluded from non-GAAP earnings are of greater quality by documenting that these exclusions are transitory and non-recurring. ${ }^{6}$ However, the disclosure requirements under Regulation $G$ imposed a significant administrative burden on firms. This resulted in some firms abandoning the reporting of non-GAAP earnings metrics in their press releases (Heflin and $\mathrm{Hsu}, 2008)^{7}$

Motivated by concerns that the restrictive nature of Regulation $G$ precludes firms from providing meaningful non-GAAP information, the SEC issued new interpretive guidance (C\&DIs) on January 11, 2010. This interpretive guidance replaced earlier guidance from 2003 and 2004 relating to the FAQs. ${ }^{8}$ For example, Question 8 previously imposed considerable burden on firms by requiring them to "demonstrate the usefulness of any measure that excludes recurring items". Demonstrating "usefulness" was a major hurdle that may have discouraged firms from disclosing non-GAAP earnings. The new C\&DIs eliminate this hurdle and allow firms flexibility in adjusting for recurring items, provided these items are not labelled as non-recurring. ${ }^{9}$ Figure 1 presents a timeline of Regulation $G$ and C\&DIs.

As C\&DIs are non-statutory, it is possible for firms to not respond to them. Alternatively, these interpretations may function as efficiently as an actual regulation (for instance, where firms seek to comply with the C\&Dls in order to minimise the risk of investigation or prosecution by the SEC (Kyung and Weintrop, 2016)). Thus, the interpretations may

Kolev et al. (2008) report that the quality of exclusions increased following the intervention of the SEC into non-GAAP reporting (post-Regulation $G$ ). Furthermore, their results indicate that the average quality has improved and that the firms that stopped releasing non-GAAP financial metrics generally tended to have lower quality exclusions before the SEC intervention period. However, they also find that the quality of special items has declined following SEC intervention, as managers adapted to the new disclosure environment by switching more recurring expenses into special items. This result highlights the unintended consequences arising from Regulation $G$ (Kolev et al., 2008). Heflin and Hsu (2008) find that Regulation $G$ generated: (i) a modest decrease in non-GAAP earnings disclosures, (ii) a decrease in the magnitude of the differences between GAAP and non-GAAP earnings (i.e. total exclusions), (iii) a modest decrease in the probability firms report non-GAAP earnings that meet or slightly exceed analysts' expectations, and (iv) a decrease in the relation between returns and earnings forecast errors. They conclude the regulation reduced the frequency and magnitude of nonGAAP earnings because the regulations enhanced managerial emphasis upon GAAP earnings. They also find that, before the regulation, managers were using other exclusions to help them meet or exceed the earnings forecast benchmarks and that the regulation has helped reduce this opportunistic managerial behaviour.

8 Form 8-K is the form on which public companies report, on a current basis, the occurrence of significant corporate events. A reportable event is a transaction or occurrence of major significance that identifies the non-GAAP financial measures contained in the incorporated reports and provides the required reconciliation. The SEC periodically expands the list of items requiring disclosure on Form 8-K and alters the time within which a Form 8-K must be filed (Source: http://www.sec.gov/answers/form8k.htm).

For instance, prior guidance prohibited firms to adjust a non-GAAP financial performance measure to eliminate or smooth items identified as "non-recurring, infrequent, or unusual" when the nature of the charge or gain is such that it is reasonably likely to recur within two years or there was a similar charge or gain within the prior two years. The new C\&DIs (Question 102.03) clarifies that this prohibition is based on the "description" of the charge or gain being adjusted. In particular, firms can adjust for the charge or gain as they deem appropriate, as long as this charge or gain is not described as non-recurring, infrequent or unusual. 
influence SEC registrants' disclosure practices even though they are non-binding (Kyung and Weintrop, 2016). Empirical evidence on the effectiveness of C\&DIs is scarce, with the exception of Kyung and Weintrop (2016). Using data from 2006 to 2013, they first examine 3-day cumulative abnormal returns surrounding the announcement of C\&Dls for two groups of firms: (i) firms reporting non-GAAP earnings informatively, and (ii) firms reporting nonGAAP earnings aggressively. ${ }^{10}$ They find that the announcement of the new C\&DIs is positively associated with the 3-day cumulative abnormal returns for firms reporting nonGAAP earnings informatively. Their results suggest that investors viewed C\&DIs as an important SEC intervention, despite the fact that the C\&DIs are non-statutory, and they affected managers' reporting behaviours, although the benefits appeared to be limited to firms using non-GAAP reporting informatively. The authors then turned their attention to aggressive non-GAAP reporters in the post-C\&DIs period and find that managers are more likely to report non-GAAP earnings aggressively when the firm's corporate governance system is poor. Overall their findings highlight that the introduction of C\&Dls is an economically important event which improved the quality of information contained in voluntary disclosures.

\section{INSERT FIGURE 1 HERE}

\subsection{Hypothesis development}

Theory suggests that both the information and the opportunism hypotheses explain managers' non-GAAP reporting decisions. Empirical findings support both hypotheses.

Consistent with the information hypothesis, non-GAAP earnings have been found to be more informative to investors relative to GAAP financial metrics, when GAAP earnings are more subjective (e.g. Bhattacharya et al., 2003; Bradshaw and Sloan, 2002; Brown and Sivakumar, 2003; Choi et al., 2007; Lougee and Marquardt, 2004). Non-GAAP financial metrics are also more predictive of future performance, consistent with these earnings numbers providing a better representation of "core" earnings (Brown and Sivakumar, 2003). However, consistent with the opportunism hypothesis, empirical findings suggest that exclusions of transitory losses from non-GAAP earnings are related to future operating performance, suggesting that these exclusions recur in subsequent periods of firm's financial reporting (e.g. Black and Christensen, 2009; Kolev et al., 2008; McVay, 2006).

The first and second hypotheses of this study address the quality of exclusions, while the third hypothesis explores the relevance of non-GAAP earnings for market participants. The first hypothesis, like Kolev et al. (2008), postulates a quality change for total exclusions, measured by the relationship of exclusions and non-GAAP earnings with future earnings:

$\mathrm{H} 1$ : The SEC's issuance of Regulation G/C\&DIs does not change the quality of the total exclusions and their components (i.e. special items and other exclusions) from nonGAAP earnings.

Under the information hypothesis, if analysts anticipate and can identify all real nonGAAP exclusions in their expectations, positive non-GAAP exclusions should not be associated with a greater incidence of meeting or exceeding analysts' forecasts. Under the opportunism hypothesis, in contrast, managers construct non-GAAP earnings to mislead 
analysts, resulting in meeting or slightly exceeding analysts' forecasts (Doyle et al., 2013). Accordingly, it is hypothesised (in the null form) as follows:

$\mathrm{H} 2$ : $\quad$ Firms using positive exclusions from non-GAAP earnings to increase non-GAAP earnings financial metrics are as likely to meet or slightly exceed analysts' forecasts following Regulation G/C\&DIs.

The third hypothesis postulates that both Regulation $G$ and C\&DIs improve the quality of non-GAAP earnings reported by improving the exclusion process. If, post-regulation, the quality of (non-GAAP) earnings has increased, then such earnings can be said to be more informative and therefore less ambiguous. Accordingly, under the information hypothesis, a stronger market response to earnings announcements would be expected (i.e. a higher ERC). In contrast, under the opportunism hypothesis, managers are expected to use the additional latitude to exclude recurring expenses and meet the analyst forecasts using exclusions. If investors understand this, a lower announcement return is expected. Accordingly, the market response hypothesis (in the null form) is:

H3: $\quad$ Earnings Response Coefficients (ERCS) for firms in the post-Regulation $G$ period/postC\&DIs period are no different than in the pre-period. ${ }^{11}$

\section{Empirical tests}

With data from IBES, CRSP, and Compustat, the empirical tests examine two distinct sample periods, with some overlap. For the Regulation $G$ change, quarterly announcements from 1998 to 2008 inclusive (5 years before and 5 years after) are used. For the C\&DIs change, quarterly announcements from 2005 to 2015 (also 5 years before and after) are used. ${ }^{12}$ The final sample includes 69,800 and 67,874 firm-quarter observations respectively, with some variation where data for specific variables are not available.

The use of IBES actual earnings per share (IBES item VALUE) to proxy for the non-GAAP earnings figures reported by managers in press releases is consistent with prior research (e.g. Bradshaw and Sloan, 2002; Doyle et al., 2003; Heflin and Hsu, 2008; Kolev et al., 2008; Kyung and Weintrop, 2016). IBES uses the quarterly press release as its source for the actual earnings per share; Bhattacharya et al. (2003) find that over 65 percent of their non-GAAP earnings figures hand-collected from press releases perfectly match the IBES actual earnings numbers. ${ }^{13,14}$

This study estimates a variable, Total_Exclusions as Non_GAAP_Earnings (i.e. Compustat actual earnings per share [IBES item VALUE]) less GAAP_Earnings (i.e. earnings per share

$11 \mathrm{H} 1, \mathrm{H} 2$ and $\mathrm{H} 3$ are examined using all firms pre- and post- Regulation G/C\&DIs. In additional analyses (Section 4.5), the study restricts the sample to only include non-GAAP reporters. Removal of 2008 data to eliminate the effects of the global financial crisis did not change the main results, and so results with 2008 data are retained. Further, investors focus most on IBES derived exclusions, implying that it is most informative to determine the underlying reasons for these exclusions, while using IBES actual earnings maximises the statistical power of the analysis (Marques, 2006). Note that the IBES GAAP dataset is quite sparse. This study initially compares the IBES and Compustat GAAP earnings distributions, and finds differences only in the extreme tails. Given the larger number of data-points in Compustat, Compustat GAAP earnings are winsorized at $0.001 \%$ in each tail, yielding a similar distribution to IBES non-GAAP earnings. This winsorized Compustat GAAP number was then used for the remainder of the tests. 
before extraordinary items from CRSP/Compustat [EPSPXQ]). Following Doyle et al. (2003; 2013) and Kolev et al. (2008), the variable Special_Items is determined as operating earnings per share from Quarterly CRSP/Compustat data (OPEPSQ) less GAAP_Earnings per share. Other_Exclusions are determined as Total_Exclusions less Special_Items. A positive value of Total_Exclusions, Special_Items and/or Other_Exclusions indicates an income-decreasing expense was excluded from non-GAAP Earnings. POST is an indicator variable that equals one if the observation falls on or after $q 12003$ for Regulation $G$ sample, as well as on or after q1 2010 for C\&DIs, and zero otherwise, respectively.

The dependant variable for $\mathrm{H} 1$ is SUM_FutOpEarn, determined as operating earnings per share from (Compustat item OPEPSQ) summed over quarters $q+1$ through quarter $q+4 .{ }^{15}$ For $\mathrm{H} 2$, the dependent variable is MEF (Meet or Exceed Analysts' Forecasts), which is an indicator variable equal to one if the current quarter $q$ earnings surprise ${ }^{16}$ is greater than or equal to zero, and zero otherwise. Finally, for $\mathrm{H} 3$, the dependent variable is 3 _day_CAR, constructed using a market model estimated from the firm's value-weighted return (inclusive of dividends and other distributions) and the value-weighted S\&P 500 as a market portfolio from CRSP Daily Stock/Security file, from one day before to one day after the IBES earnings announcement date. ${ }^{17}$ Following Doyle et al. (2003; 2013), all continuous independent variables (except returns) are decile-ranked and take values between zero and one (i.e. $\frac{\text { decile-1 }}{9}$ ).

Control variables are identified based on previous studies (Frankel et al., 2011; Kolev et al., 2008) - Growth, Loss, Earnings_Volatility, and Book_to_Market_Assets - each of which are anticipated to be correlated with both Non_GAAP_Earnings and FutureOperating_Earnings. ${ }^{18}$ The analysis further includes the natural logarithm of Total Assets (Size) to deal with skewness in the distribution of the dependant variables. To further control for size effects in the analysis (following Frankel et al., 2011), variables such as SUM_FutOpEarn, GAAP_Earnings, Non_GAAP_Earnings, Total_Exclusions, Special_Items, Other_Exclusions, and Growth are standardised by total assets per share. All continuous variables are further winsorized at the top and bottom two percent to avoid undue influence

15 Curtis et al. (2014), Frankel et al. (2011), Kolev et al. (2008) and Kyung and Weintrop (2016) propose that this dependent variable is well suited for exploring the research questions since operating earnings per share as determined by Quarterly CRSP/Compustat data excludes transitory and nonrecurring special items but contains recurring components that might appear in firms' other exclusions from non-GAAP earnings. As such, it most approximates the notion of more persistent and permanent earnings. This is constructed as Non_GAAP_Earnings less the median value of IBES actual earnings [IBES item MEDEST].

17 This study also undertakes the analyses using raw 3-day returns and market-adjusted 3-day returns, using the same market index. As there is no qualitative difference between the results, the study reports results using CAR.

Those control variables are identified as follows, with Quarterly CRSP/Compustat and CRSP Daily Stock/Security data: Growth is the increment in sales revenue (CRSP/Compustat item SALEQ) over the same quarter in the prior year, scaled by total assets. Size is the natural logarithm of the firm's total assets at the end of quarter (CRSP/Compustat item ATQ). Loss is an indicator variable equal to one if GAAP_Earnings figure in quarter $q$ is less than zero, and zero otherwise. Earnings_Volatility is the standard deviation of return on assets (ROA) [CRSP/Compustat item NIQ divided by CRSP/Compustat item ATQ] over the previous two years (i.e. eight preceding quarters). Book_to_Market_Assets is the book value of equity (CRSP/Compustat item CEQQ) divided by the book value of debt (CRSP/Compustat item DLCQ plus CRSP/Compustat item DLTTQ) plus market value of equity (CRSP/Compustat item PRCCQ multiplied by CRSP/Compustat item CSHOQ) at the end of the quarter. 
by outliers. ${ }^{19}$ The ordinary least squares (OLS) regressions are estimated with robust standard errors.

In this study, high quality exclusions are considered to be those which have the least predictive power for future operating earnings, as per Kolev et al. (2008). The average quality of exclusions for a period is estimated by determining the strength with which nonGAAP exclusions map into future earnings. $\mathrm{H} 1$ is therefore tested by estimating, separately for Regulation $G$ and $C \& D I s$, the following cross-sectional pooled regression equation:

$$
\begin{aligned}
& \text { SUM_FutOpEarn } \text { q }_{q+1} \text { to } q+4=B_{0}+B_{1} \text { Non_GAAP_Earnings }_{q}+B_{2} \text { Total_Exclusions }{ }_{q}+ \\
& B_{3} \text { POST }+B_{4} \text { Total_Exclusions } q \times \text { POST }+B_{5} \text { Growth }+B_{6} \text { Size }+b_{7} \text { Loss }+
\end{aligned}
$$

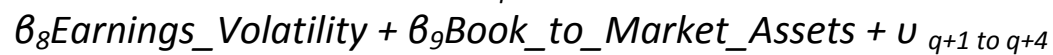

where:

$\begin{array}{ll}\text { SUM_FutOpEarn: } & \begin{array}{l}\text { operating earnings per share from CRSP/Compustat (OPEPSQ) } \\ \text { summed over quarters from } q+1 \text { through } q+4 ; \\ \text { basic earnings per share before extraordinary items from } \\ \text { GAAP_Earnings: }\end{array} \\ \text { CRSP/Compustat (EPSPXQ); }\end{array}$

Total_Exclusions: Non_GAAP_Earnings less GAAP_Earnings;

POST:

an indicator variable that is equal to one if the firm-quarter observation occurs after 2003q1 (inclusive, for the Regulation $G$ change) or after $2010 q 1$ (inclusive, for the C\&DIs change), and zero otherwise;

Special_Items: $\quad$ operating income (CRSP/Compustat item OPEPSQ) less GAAP_Earnings from CRSP/Compustat;

Other_Exclusions: Total_Exclusions less Special_Items; a positive value of Total_Exclusions, Special_Items, and/or Other_Exclusions indicates an income-decreasing expense was excluded from non-GAAP earnings;

Growth: incremental in sales revenue (CRSP/Compustat item SALEQ) over the same quarter in the prior year, standardised by Total Assets;

Size: $\quad$ natural logarithm of total assets (CRSP/Compustat item ATQ) corresponding to quarter $q$;

Loss: $\quad$ an indicator variable equal to one if GAAP_Earnings for the quarter is less than zero, and zero otherwise;

Earnings_Volatility: standard deviation of return on assets (ROA) over preceding eight quarters (CRSP/Compustat item NIQ divided by CRSP/Compustat item ATQ); and

Book_to_Market_Assets: book value of equity (CRSP/Compustat item CEQQ) divided by the book value of debt (CRSP/Compustat item DLCQ plus CRSP/Compustat item DLTTQ) plus market value of equity (CRSP/Compustat item PRCCQ multiplied by CRSP/Compustat item (SHOQ).

To determine whether Special_Items and Other_Exclusions have different effects, a disaggregated version of Equation 1 is also estimated: percent due to the extreme values of exclusion variables and of the Growth control variable. 


$$
\begin{aligned}
& \text { SUM_FutOpEarn } q+1 \text { to } q+4=B_{0}+B_{1} \text { Non_GAAP_Earnings } q+B_{2} \text { Special_Items }{ }_{q}+ \\
& B_{3} \text { Other_Exclusions } q+B_{4} P O S T+B_{5} \text { Special_Items } q \times P O S T+B_{6} \text { Other_Exclusions } q \\
& \times \text { POST }+b_{7} \text { Growth }+b_{8} \text { Size }+b_{9} \text { Loss }+b_{10} \text { Earnings_Volatility }+ \\
& B_{11} \text { Book_to_Market_Assets }+U_{q+1} \text { to } q+4
\end{aligned}
$$

The second hypothesis, $\mathrm{H} 2$, addresses whether - irrespective of the intrinsic properties of the relationship between exclusions and future earnings - the exclusion process is associated with the extent to which realised future earnings relate to expectations, measured by analysts' forecasts. This is articulated as the ability of earnings to meet or beat analyst forecasts. If there is an incentive to meet or beat, the use of positive exclusions will be more salient for achieving this benchmark, while the use of negative exclusions do not aid in doing so. $\mathrm{H} 2$ is tested using a probit regression with MEF (meet or beat) as the dependant variable, and the same set of explanatory variables. The following equations are estimated:

$$
\begin{aligned}
& M F_{q}=b_{0}+b_{1} \text { Positive_Total_Exclusions } q+b_{2} \text { POST }+b_{3} \text { Positive_Total_Exclusions } q \\
& \text { POST }+B_{4} \text { SOX }+B_{5} \text { Positive_Total_Exclusions } q \times S O X+B_{6} \text { Growth }+b_{7} \text { Size }+ \\
& B_{8} \text { Loss }+B_{9} \text { Earnings_Volatility }+B_{10} \text { Book_to_Market_Assets }+U_{q} \\
& +b_{9} \text { Growth }+b_{10} \text { Size }+b_{11} \text { Loss }+b_{12} \text { Earnings_Volatility }+ \\
& B_{13} \text { Book_to_Market_Assets }+U_{q}
\end{aligned}
$$

where variables are as previously defined, with the following additional variables:

MEF:

Meet or Exceed Analysts' Forecasts, an indicator variable equal to one if the current quarter $q$ of earnings surprise (i.e. Non_GAAP_Earnings less median IBES actual earnings [IBES item MEDEST] as earnings benchmarks) is greater than or equal to zero, and zero otherwise;

Positive_Total_Exclusions: magnitude of positive Total_Exclusions;

Positive_Special_Items: magnitude of positive Special_Items;

Positive_Other_Exclusions: magnitude of negative Other_Exclusions; and

SOX: $\quad$ an indicator variable set to equal one if quarter $q$ is the third quarter of 2002, zero otherwise.

In Equation (3), if the coefficient on the Positive_Total_Exclusions variable $\left(B_{1}\right)$ is positive and statistically significant in explaining the current quarter of MEF (Meet or Exceed Analysts' Forecasts), this indicates that firms using positive exclusions from non-GAAP earnings tend to meet or exceed expectations more often in the pre-event periods.

While $\mathrm{H} 1$ is similar to Kolev et al. (2008), this study extends their analyses to consider whether C\&Dls also impact on the quality of non-GAAP exclusions. While $\mathrm{H} 2$ is similar to Heflin and Hsu (2008), the study extends their work by investigating how Regulation $G$ and C\&DIs impact on the use of positive exclusions to meet or beat analysts' forecasts. Finally, $\mathrm{H} 3$ extends the investigation - beyond consideration of how the non-GAAP announcement information maps into future earnings and analyst accuracy - to consider the impact SEC 
interventions have had on price informativeness of earnings, through ERCs. The extent of the change in ERCs will depend on the level of exclusions, i.e. the extent to which profits are adjusted for the announcement. Thus, indicator variables are included for positive exclusions to examine the effect of firms using income-increasing exclusions, in comparison to those without, as follows:

$$
\begin{aligned}
& \text { 3_day_CAR } q=B_{0}+b_{1} \text { Surprise }_{q}+B_{2} \text { Positive_Total_Exclusions } q+B_{3} \text { POST }+b_{4} \text { Surprise }_{q} \\
& \times \text { POST }+B_{5} \text { Growth }+B_{6} \text { Size }+b_{7} \text { Loss }+B_{8} \text { Earnings_Volatility }+ \\
& B_{g} B o o k \text { to_Market_Assets }+U_{q} \\
& \text { 3_day_CAR } q=B_{0}+B_{1} \text { Surprise }_{q}+B_{2} \text { Positive_Special_Items } q+ \\
& B_{3} \text { Positive_Other_Exclusions } q+B_{4} P O S T+B_{5} \text { Surprise } q \times P O S T+B_{6} \text { Growth }+ \\
& B_{7} \text { Size }+b_{8} \text { Loss }+b_{9} \text { Earnings_Volatility }+b_{10} \text { Book_to_Market_Assets }+u_{q}
\end{aligned}
$$

where variables are as previously defined, with the following additional variables:

3_day_CAR: $\quad$ aggregates Cumulative Abnormal Residuals (CAR) over 3 days surrounding the earnings announcement, using parameters constructed using a market model estimated (over days -150 to -20 relative to the announcement) from the firm's value-weighted return (inclusive of dividends and other distributions) and the value-weighted S\&P 500 as a market portfolio from CRSP Daily Stock/Security file; and

Surprise:

a firm's earnings surprise (Non_GAAP_Earnings less the consensus median earnings forecast [IBES item MEDEST]) divided by the firm's market price (CRSP/Compustat item PRCCQ).

\section{Results and discussion}

\subsection{Descriptive statistics and correlations}

Table 1 presents the descriptive statistics for the main dependent and independent variables. All continuous variables are winsorized at the top and bottom two percent to mitigate the effects of extreme outliers. For the Regulation $G$ sample $(69,800$ firm-quarter observations), the mean (median) GAAP_Earnings per share is 0.0039 (0.0087) and Non_GAAP_Earnings per share is 0.0052 (0.0076). This indicates that Non_GAAP_Earnings, on average, exceed GAAP_Earnings. The mean of Total_Exclusions, Special_Items, and Other_Exclusions is $0.0013, \overline{0} .0031$ and -0.0017 , respectively. ${ }^{20}$

\section{INSERT TABLE 1 HERE}

For the C\&DIs sample (67,874 firm-quarter observations), Non_GAAP_Earnings per share has a higher mean (0.0075) and median (0.0100) in the C\&DIs sample than the Regulation $G$ sample. The mean of Total_Exclusions is also higher in the C\&DIs sample. Special_Items are larger in magnitude in the Regulation $G$ period than the C\&DIs period 0.0031 and 0.0026 , respectively. However, Other_Exclusions are larger in the C\&DIs period (0.0003), compared with -0.0017 in the Regulation G period. SUM_FutOpEarn are also larger at 0.0323 for the C\&DIs period as compared to 0.0267 for the Regulation $G$ period. 
The mean (median) of Growth is 0.0216 (0.0134) for the Regulation $G$ period and 0.0159 (0.0093) for the C\&Dls period. ${ }^{21}$ Finally, Earnings_Volatility is similar in the Regulation $G$ sample and the C\&DIs sample. Lougee and Marquardt (2004) indicate that firms with high earnings volatility (e.g. IT technology and pharmaceutical firms with high R\&D) are more likely to be associated with the disclosure of non-GAAP earnings.

Descriptive statistics are reported for raw 3-day returns (3_day_RAW) and 3-day market adjusted returns (3_day_MAR), as well as 3-day CARs (3_day_CAR). The remainder of the study reports results using only 3 _day_CAR, as results using the other return measures (not tabulated) are qualitatively the same.

\section{INSERT TABLE 2 HERE}

Table 2 presents a pairwise correlation matrix with the main dependent and independent variables. Total_Exclusions are negatively correlated with GAAP_Earnings for Regulation $G(\rho=-0.6798)$ and C\&DIs $(\rho=-0.6568)$. This suggests that poorly performing firms (based on operating earnings) are more likely to disclose non-GAAP earnings. SUM_FutOpEarn are positively correlated with GAAP_Earnings for Regulation $G(\rho=0.7631)$ and C\&DIs $(\rho=0.7321)$, and are more strongly positively correlated with Non_GAAP_Earnings for Regulation $G(\rho=0.7899)$ and C\&DIs $(\rho=0.7909)$. This is consistent with prior research (e.g. Bradshaw and Sloan, 2002; Bhattacharya et al., 2003; Frankel and Roychowdhury, 2005) that Non_GAAP_Earnings are more permanent and relevant than GAAP_Earnings in a firm's valuation.

Further, Total_Exclusions and SUM_FutOpEarn are negatively correlated for Regulation $G(\rho=-0.3322)$ and C\&DIs $(\rho=-0.2416)$; this is consistent with Kolev et al. (2008) who also find non-GAAP earnings may eliminate income-decreasing expenses associated with SUM_FutOpEarn. Moreover, Special_Items are negatively correlated with GAAP_Earnings and Non_GAAP_Earnings for both SEC events. MEF is positively correlated with Non_GAAP_Earnings $(\rho=0.1541)$ but negatively correlated with Total_Exclusions ( $\rho=-$ 0.0638), and positively correlated with SUM_FutOpEarn $(\rho=0.1204)$ and GAAP_Earnings ( $\rho$ $=0.1483$ ) for the Regulation $G$ period. This suggests that meeting or exceeding analysts' forecasts is associated with both Non_GAAP_Earnings and GAAP_Earnings, although the non-GAAP correlation appears greater. Similar results for MEF correlation with above variables appear in the C\&DIs sample. Finally, Surprise is positively correlated with 3_day_CAR in both event periods.

\subsection{Results for $\mathrm{H1}$}

\section{INSERT TABLE 3 HERE}

Table 3 presents the results for $\mathrm{H} 1$, which considers how exclusions map into future earnings. Cross-sectional pooled OLS regressions are estimated with robust standard errors. Total_Exclusions are negatively related with SUM_FutOpEarn for both Regulation G $(-0.0086)$ and C\&DIs (-0.0065). This suggests that non-GAAP exclusions are not perfectly transitory items (i.e. recurring items) during both SEC interventions.

$21 \quad$ Kolev et al. (2008) find that the mean (median) sales growth is 0.387 (0.160) for the Regulation $G$ period. When this study calculates growth using Kolev et al. (2008)'s method, a similar mean (median) of $0.31(0.05)$ across both samples are obtained. However, Kolev et al. (2008)'s calculation involves taking a difference in sales dollars and dividing by the number of shares, yielding a dollar dimensionality rather than a dimensionless number. Growth is calculated by dividing change in dollar value by total assets, thus expressing growth as percentage of total assets. 
Further, the interaction variable between Total_Exclusions and POST tests whether the disclosure of non-GAAP earnings has enhanced the quality of non-GAAP exclusions following the implementation of Regulation $G$ and C\&DIs. The coefficient on this interaction is positive and significant in both the Regulation $G$ and C\&DIs periods; comparing magnitudes, the effect of this interaction on non-GAAP exclusions is to make the latter less negative. This indicates that the quality of exclusions from non-GAAP earnings is significantly improved in the period after each SEC intervention (i.e. where more transitory items are excluded). Thus, this result is consistent with the information hypothesis, which posits that the quality of non-GAAP earnings exclusions has been enhanced after Regulation $G$ and C\&DIs.

$\mathrm{H} 1$ also considers whether Regulation $G$ and C\&DIs affect the quality of the exclusion components (i.e. Special_Items and Other_Exclusions). The coefficients on Special_Items are positive and significant at the one percent level for both Regulation $G$ and C\&DIs (0.0006 and 0.0012 , respectively). The interaction between Special_Items and POST is negative and significant for the C\&DIs period $(-0.0003)$. Thus, the sum of Special_Items and this interaction term becomes less positive after the introduction of C\&DIs. This suggests that the quality of Special_Items enhances after the introduction of C\&DIs, as the amount of excluded special items post-implementation is less informative about future earnings. ${ }^{22}$ Doyle et al. (2003) and Doyle et al. (2013) argue that Other_Exclusions are considered as low-quality exclusions because those are significantly predictive for SUM_FutOpEarn, determined by managers' own voluntary discretions, and used opportunistically to mislead investors before the SEC intervention. The coefficients on Other_Exclusions are negative and significant at the one percent level for both Regulation $G$ and C\&DIs (-0.0091 and -0.0076 , respectively). The interaction variables between Other_Exclusions and POST are positive (0.0012 and 0.0013) and significant for both Regulation $G$ and C\&Dls. These results suggest that the quality of Other_Exclusions has improved following Regulation $G$ and C\&Dls (i.e. more transitory items in the Other_Exclusions component). These results are consistent with Kolev et al. (2008) who find Other_Exclusions are more transitory after Regulation G.

In addition to the mapping of exclusions into future operating earnings, this study also tests how exclusions map into future returns. Specifically, the study examines the 3-day CAR at the $\mathrm{q}+4$ (Future4CAR3), as well as at $\mathrm{q}+1$ (Future1CAR3). Results are shown in Tables 4 and 5 respectively. For Future4CAR3, there is a negative relationship with Total_Exclusions before Regulation $G(-0.0004)$ and C\&DIs $(-0.0003)$. While the incremental coefficient is enough to reverse the sign of the coefficient for C\&DIs (Total_Exclusions -0.0003; Total_Exclusions $\times P O S T$ 0.0006), the magnitude for Regulation $G$ is unchanged (Total_Exclusions -0.0004; Total_Exclusions $\times P O S T$ is not significant). This suggests that investors are partly "fooled" by the exclusion process around Regulation $G$ and before C\&DIs (not after).

The results for Future1CAR3 (the subsequent quarter, Table 5) show there is a negative relationship with Total_Exclusions and their components before Regulation $G$, and the incremental coefficient does not change this (Total_ExclusionsXPOST is not significant). The

22 In contrast, Kolev et al. (2008) finds that the coefficient on special items is significantly positive and the estimated coefficient on the interaction between special items and POST is negative and significant. Although the signs are different, the reduction in the overall strength of the relationship between special items and future earnings is consistent with special item removal enhancing the quality of earnings. 
coefficients on Total_Exclusions and Total_ExclusionsXPOST are, however, not significant for C\&DIs.

The quarter +4 results indicate that around Regulation $G$ and before C\&DIs, price seems to incorrectly impound the information content of announced earnings, since the price response four quarters later seems to be related to the components of the originally announced earnings. The lack of change to the quarter+1 announcement should, however, be interpreted with care as there may be other, seasonal/quarterly factors that impact on this lack of relationship.

\section{INSERT TABLE 4 HERE \\ INSERT TABLE 5 HERE}

In both Regulation $G$ and C\&Dls for each forward CAR measure, there is (with the exception of Future4CAR3 for the Regulation G Total_Exclusions model) a significant negative coefficient on POST; this suggests that market response to subsequent announcements is reduced after Regulation $G$ and C\&Dls. This pattern suggests that exclusions allow investors to anticipate future announcements, leading to a lower future $(q+1, q+4)$ response after Regulation $G$ and C\&Dls.

\subsection{Results for $\mathrm{H} 2$}

Table 6 presents the results for $\mathrm{H} 2$, which hypothesises that firms using positive exclusions from non-GAAP earnings to increase non-GAAP earnings financial metrics are as likely to meet or slightly exceed analysts' forecasts following Regulation $G$ and the SEC's issuance of C\&DIs. A probit regression is used to examine the effect of non-GAAP exclusions on the probability of exceeding consensus forecasts. If managers opportunistically report non-GAAP earnings to meet or slightly exceed analysts' forecasts, one would expect a positive relation between positive exclusions and the MEF dependent variable (e.g. Doyle et al., 2013). The main independent indicator variable, Positive_Total_Exclusions, is equal to the magnitude of total exclusions. The coefficient for this variable is significantly positive for both Regulation $G$ (3.7230) and C\&DIs (2.1068).

\section{INSERT TABLE 6 HERE}

This suggests that, prior to Regulation $G$ and C\&DIs, the use of positive total exclusions helps firms meet or beat analysts' forecasts. When Total_Exclusions is replaced by Special_Items and Other_Exclusions, both the special items and other exclusions components are associated with meet or beat prior to both Regulation $G$ (coefficient on Special_Items 3.8188; coefficient on Other_Exclusions 3.8577) and the introduction of the C\&DIs (coefficients 2.4305 and 4.4667, respectively).

Furthermore, this study finds that Regulation $G$ reduced the use of total exclusions to meet or beat forecasts: the significant coefficient on the interaction term Positive_Total_ExclusionsxPOST (-0.5639), when added to the coefficient on Positive_Total_Exclusions significantly reduces the total coefficient. The study finds similar results on Positive_Special_ItemsXPOST (-0.8765). For the C\&DIs sample, all interactions are positive. Overall, the results suggest that firms using positive non-GAAP earnings exclusions, particularly to increase non-GAAP earnings metrics, are less likely to meet or exceed analysts' forecasts following Regulation $G$, but that C\&DIs relax the environment, enabling the use exclusions to increase the likelihood of meeting or beating analysts' forecasts. 


\subsection{Results for $\mathrm{H3}$}

Table 7 presents the results for H3. The dependent variable, 3_day_CAR is defined as the aggregated 3-day excess return around the announcement. Following Doyle et al. (2003; 2013), all independent variables are decile-ranked and take a value between zero and one (i.e. $\frac{\text { decile-1 }}{9}$ ). Earnings response coefficients (ERCs) are the coefficients on earnings Surprise, while the coefficient on SurprisexPOST represents the change in ERC post-SEC interventions.

\section{INSERT TABLE 7 HERE}

The sample includes firms that report non-GAAP earnings and firms that choose not to. The study also examines whether the effect on ERC is driven by firms that utilise non-GAAP earnings in their reports. In Table 7, an interaction term between SurprisexPOST is included, as well as a three-way interaction of these components with an indicator variable reflecting the use of non-GAAP numbers (NonGAAPusage defined as zero if GAAP earnings are equal to announced non-GAAP earnings, one otherwise). This three-way interaction term (NONGAAPusagexSurprisexPOST) is significantly positive for Regulation $G(0.2212)$ and negative for C\&DIs (-0.2253). The results suggests that post-Regulation $G$, the ERCs of firms reporting non-GAAP earnings increased substantially more than for those that did not, indicating that Regulation $G$ increased the quality of earnings. In contrast, for C\&DIs, the coefficient on the three-way-interaction is negative, suggesting that the relaxation of regulation afforded through the C\&Dls resulted in less informative earnings for firms that report non-GAAP earnings.

\subsection{Additional analyses}

Additional analyses were undertaken to further determine the robustness of the results. These include: analysis with both winsorized and unwinsorized variables (except for exclusions); explicit one-way (firm) and two-way (firm and year) clustering of standard errors; and analysing only those firms which are users of non-GAAP reporting, where this is defined as having non-zero exclusions for at least 80 percent of quarters preceding each SEC intervention. The main results reported in this study do not change. To confirm the integrity of the dataset used in this study, replications of Doyle et al. (2013) and Heflin and Hsu (2008) are conducted which yield consistent results.

Mapping exclusions into future returns, rather than future earnings, was also explored as an alternative method of assessing their information content. The results (not tabulated) indicate a significant and consistent set of results for total exclusions when mapping into post-Regulation $G$ returns over 4 years and 1 year, but not over the ensuing quarter. The results are not consistent for C\&DIs. As the discussion in this study focuses on the properties of accounting numbers rather than the process of markets impounding this information, only the mapping of exclusions into future earnings around Regulation $G$ and C\&DIs has been reported. Nonetheless, the inconsistency around C\&DIs reinforced the overall findings of this study - the regulatory effect of Regulation $G$ was more pronounced than that of the C\&DIs.

\section{Conclusions}

This study examines a number of consequences of non-GAAP disclosure resulting from changes to SEC regulatory and interpretive guidance (i.e. Regulation $G$ and C\&DIs). This study finds that Regulation $G$ is associated with an increase in the quality of non-GAAP 
earnings exclusions. This study contributes to the existing literature by documenting that C\&DIs (despite not being a formal regulation) are also associated with an increase in the quality of non-GAAP exclusions. Furthermore, the study investigates whether Regulation $G$ and C\&Dls decrease the probability of firms using positive exclusions to meet or beat analysts' forecasts. Results indicate that while Regulation $G$ decreased the amount of total positive exclusions used to meet or beat analysts' forecasts, C\&Dls relaxed the effect of Regulation $G$, increasing the amount of exclusions used to meet or beat analysts' forecasts. Finally, it is hypothesised that the market response, measured as earnings response coefficients (ERCs), will change. However, this change will be conditional upon the extent to which the market is able to incorporate the higher quality information into the expectationforming process. The study finds an increase in the ERCs during the post-Regulation $G$ period, but a reduction post-C\&DIs period for firms using non-GAAP earnings.

Overall, results suggest that while Regulation $G$ had its intended effects, results on C\&DIs are mixed. An interesting tension arises from these mixed results. On the one hand, the introduction of C\&DIs was to reduce compliance burden, and the results suggest that the introduction of C\&DIs was successful in doing so in terms of an increase in the quality of exclusions. However, C\&DIs also resulted in an increase in the use of positive exclusions to meet or beat analysts' forecasts and lower ERCs which highlight the unintended consequences of this regulatory intervention. As the results on C\&DIs are mixed, future research is needed to further understand the costs and the benefits associated with the introduction of C\&DIs.

A key limitation of this study is the use of IBES actual earnings figures as a proxy for nonGAAP earnings. This method provides less accurate information about the incidence of disclosure of non-GAAP financial measures, as it has been established there is a significant difference between IBES actual earnings and the earnings figures reported by firms in their press releases (Bhattacharya et al., 2003). Another limitation of the study is the use of future operating earnings as a measure for current disclosure relevance. This is only a valid approach if financial information users fixate on earnings, with non-GAAP earnings being considered as "true earnings" with a measurement error. Fixation means that investors fixate upon earnings and fail to attend separately to its components, whether these are nonGAAP earnings and exclusions, or cash flows and accruals. If one of the components (nonGAAP earnings or cash flow) provides a better forecast of future operating earnings than the other (accruals or exclusions), investors who neglect this distinction become overly optimistic about the future prospects of firms with high accruals or exclusions, and overly pessimistic about the future prospect of firms with low accruals or exclusions. As a result, the former become overvalued, and subsequently earn low abnormal returns, while the latter become undervalued and are followed by high abnormal returns. The extension provided in this study, using ERCs (which reflect a real market-formed consensus between investors), examines these phenomena while addressing the fixation issue. Alternative future return metrics have also been considered.

This study has addressed the usefulness of non-GAAP earnings in terms of how such earnings, in the presence of exclusions, map into future earnings. Future research may address the degree to which current disclosures are informative about future cash flows (e.g. Arthur et al., 2010). 


\section{References}

Arthur, N., Cheng, M., Czernkowski, R. M. J., 2010. Cash flow disaggregation and the prediction of future earnings. Accounting \& Finance 50(March), 1-30.

Bhattacharya, N., Black, E. L., Christensen, T. E., Larson, C., 2003. Assessing the relative informativeness and permanence of non-GAAP earnings and GAAP operating earnings. Journal of Accounting and Economics 36, 285-319.

Black, D., Christensen, T., 2009. Managers' use of 'pro-forma' adjustments to meet strategic earnings benchmarks. Journal of Business Finance and Accounting 36, 297-326.

Bradshaw, M., Sloan, R., 2002. GAAP versus the Street: An empirical assessment of two alternative definitions of earnings. Journal of Accounting Research 40, 41-65.

Brown, L., Sivakumar, K., 2003. Comparing the value relevance of two operating income measures. Review of Accounting Studies 8, 561-572.

Brown, N., Christensen, T., Elliott, W., Mergenthaler, R., 2012. Investor sentiment and proforma earnings disclosures. Journal of Accounting Research 50, 1-40.

Choi, Y. S., Lin, S., Walker, M., Young, S., 2007. Disagreement over the persistence of earnings components: Evidence on the properties of management-specific adjustments to GAAP earnings. Review of Accounting Studies 12, 595-622.

Curtis, A., McVay, S., Whipple, B., 2014. The disclosure of non-GAAP earnings information in the presence of transitory gains. The Accounting Review 89, 933-958.

Doyle, J., Jennings, J., Soliman, M., 2013. Do managers define non-GAAP earnings to meet or beat analyst forecasts? Journal of Accounting and Economics 56, 40-56.

Doyle, J., Lundholm, R., Soliman, M., 2003. The predictive value of expenses excluded from pro-forma earnings. Review of Accounting Studies 8, 145-174.

Frankel, R., McVay, S., Soliman, M., 2011. Non-GAAP earnings and board independence. Review of Accounting Studies 16, 719-744.

Frankel, R., Roychowdhury, S., 2005. Testing the clientele effect: An explanation for nonGAAP earnings adjustments used to compute I/B/E/S earnings. Working Paper, Massachusetts Institute of Technology.

Gu, Z., Chen, T., 2004. Analysts' treatment of nonrecurring items in street earnings. Journal of Accounting and Economics 38, 129-170.

Heflin, F., Hsu, C., 2008. The impact of the SEC's regulation of non-GAAP disclosures. Journal of Accounting \& Economics 46, 349-365.

Kolev, K., Marquardt, C., McVay, S., 2008. SEC scrutiny and the evolution of non-GAAP reporting. The Accounting Review 83, 157-184.

Kyung, H., Weintrop, J., 2016. The economic consequences of SEC interpretative guidance and the effects of firm behavior: Evidence of non-GAAP earnings disclosure. Working Paper.

Lougee, B., Marquardt, C., 2004. Earnings quality and strategic disclosure: An empirical examination of pro-forma earnings. The Accounting Review 79, 769-795.

Marques, A., 2006. SEC interventions and the frequency and usefulness of non-GAAP financial measures. Review of Accounting Studies 11, 549-574.

McVay, S., 2006. Earnings management using classification shifting: An examination of core earnings and special items. The Accounting Review 81, 3: 501-531. 
Securities and Exchange Commission (SEC), 2010. Non-GAAP financial measures. Available from https://www.sec.gov/divisions/corpfin/guidance/nongaapinterp.htm (last accessed June 28th, 2016). 
Figures

Figure 1: Timeline of Regulation $G$ and C\&DIs on non-GAAP earnings

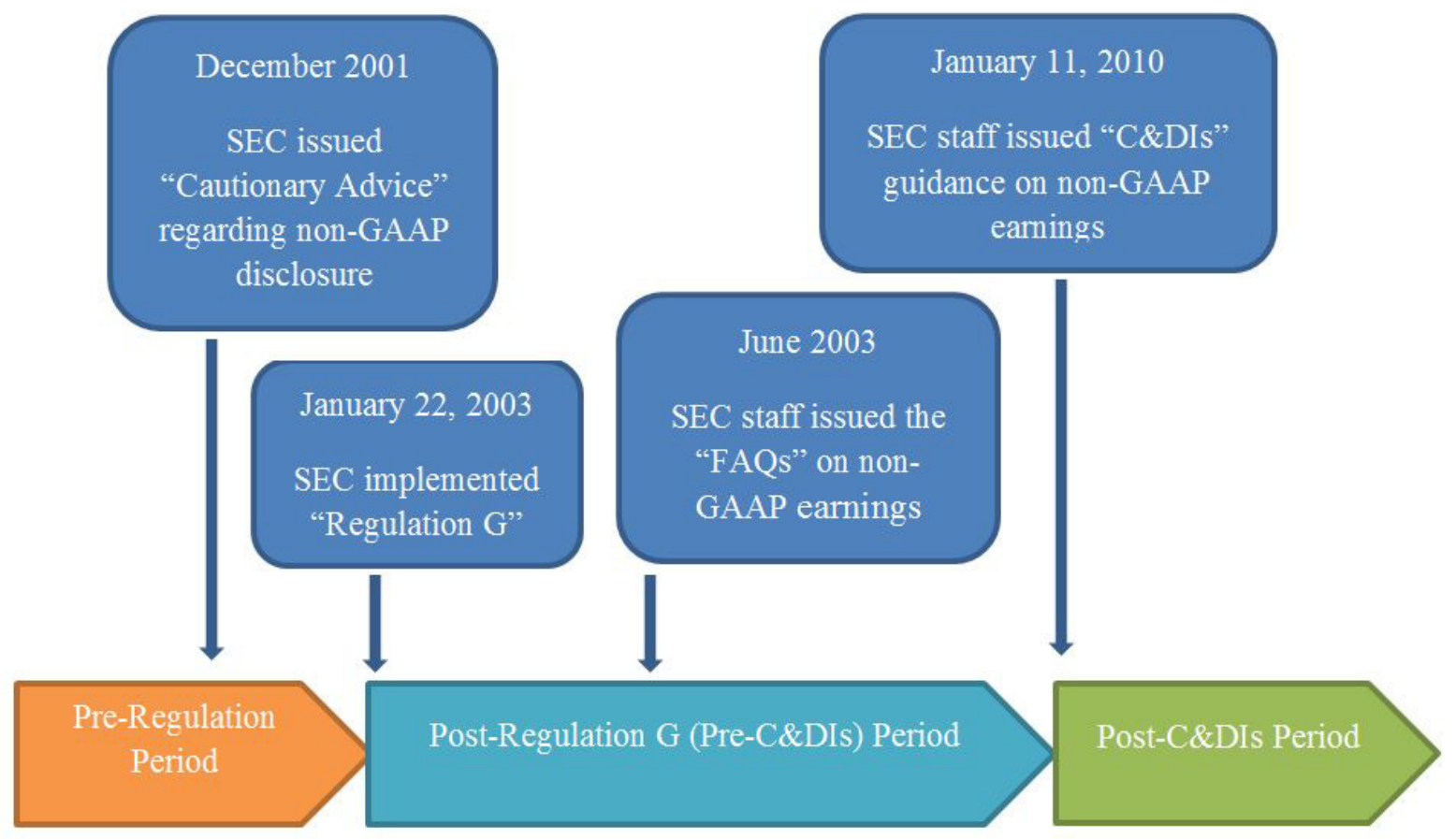


Tables

Table 1: Descriptive Statistics for Regulation $G$ and C\&DIs samples

\begin{tabular}{|c|c|c|c|c|c|c|c|c|}
\hline \multirow[b]{2}{*}{ Variables } & \multicolumn{4}{|c|}{ Regulation G } & \multicolumn{4}{|c|}{ C\&DIs } \\
\hline & $\mathbf{N}$ & Mean & Median & Std. Dev. & $\mathbf{N}$ & Mean & Median & Std. Dev. \\
\hline SUM_FutOpEarn & 69800 & 0.0267 & 0.0372 & 0.1133 & 67874 & 0.0323 & 0.0405 & 0.1082 \\
\hline Future4car3 & 68575 & 0.0013 & 0.0003 & 0.0773 & 66541 & 0.0009 & -0.0003 & 0.0754 \\
\hline Future1car3 & 69593 & 0.0017 & 0.0007 & 0.0778 & 67632 & 0.0017 & 0.0000 & 0.0758 \\
\hline GAAP_Earnings & 69800 & 0.0039 & 0.0087 & 0.0370 & 67874 & 0.0046 & 0.0092 & 0.0363 \\
\hline Non_GAAP_Earnings & 69800 & 0.0052 & 0.0076 & 0.0279 & 67874 & 0.0075 & 0.0100 & 0.0278 \\
\hline Total_Exclusions & 69800 & 0.0013 & 0.0000 & 0.0186 & 67874 & 0.0029 & 0.0000 & 0.0190 \\
\hline (non-zero only) & 52673 & 0.0017 & -0.0005 & 0.0214 & 51816 & 0.0038 & 0.0002 & 0.0217 \\
\hline Special_Items & 69800 & 0.0031 & 0.0000 & 0.0400 & 67874 & 0.0026 & 0.0000 & 0.0282 \\
\hline (non-zero only) & 23046 & 0.0092 & 0.0014 & 0.0692 & 29174 & 0.0061 & 0.0012 & 0.0428 \\
\hline Other_Exclusions & 69800 & -0.0017 & -0.0001 & 0.0368 & 67874 & 0.0003 & 0.0000 & 0.0237 \\
\hline (non-zero only) & 54373 & -0.0022 & -0.0007 & 0.0416 & 54250 & 0.0004 & -0.0002 & 0.0265 \\
\hline Growth & 69800 & 0.0216 & 0.0134 & 0.0505 & 67874 & 0.0159 & 0.0093 & 0.0485 \\
\hline Size & 69800 & 6.7796 & 6.6658 & 1.7972 & 67874 & 7.1458 & 7.0828 & 1.8248 \\
\hline Loss & 69800 & 0.2129 & 0.0000 & 0.4093 & 67874 & 0.2127 & 0.0000 & 0.4092 \\
\hline Earnings_Volatility & 69800 & 0.0198 & 0.0094 & 0.02900 & 67874 & 0.0199 & 0.0091 & 0.0294 \\
\hline Book_to_Market_Assets & 69800 & 0.3718 & 0.3253 & 0.2375 & 67874 & 0.4036 & 0.3526 & 0.2580 \\
\hline$M E F$ & 69800 & 0.5420 & 1.0000 & 0.4982 & 67874 & 0.5773 & 1.0000 & 0.4940 \\
\hline 3_day_MAR & 69800 & 0.0031 & 0.0022 & 0.0776 & 67874 & 0.0020 & 0.0003 & 0.0756 \\
\hline 3_day_CAR & 69800 & 0.0017 & 0.0008 & 0.0775 & 67874 & 0.0013 & -0.0002 & 0.0755 \\
\hline 3_day_RAW & 69800 & 0.0035 & 0.0019 & 0.0805 & 67874 & 0.0029 & 0.0014 & 0.0791 \\
\hline Surprise & 69800 & -0.0007 & 0.0002 & 0.0095 & 67874 & -0.0001 & 0.0005 & 0.0108 \\
\hline
\end{tabular}

These are the pre-winsorized data. GAAP_Earnings: basic earnings per share before extraordinary items from CRSP/Compustat (EPSPXQ); SUM_FutOpEarn: operating earnings per share from CRSP/Compustat (OPEPSQ) summed over quarters from $q+1$ through $q+4$; Future4car3: $3-$ day cumulative abnormal return around q+4; Future1car3: 3 -day cumulative abnormal return around q+1; GAAP_Earnings: basic earnings per share before extraordinary items from CRSP/Compustat (EPSPXQ); Non_GAAP_Earnings: IBES reported actual basic earnings per share (IBES item VALUE); Total_Exclusions: Non_GAAP_Earnings less GAAP_Earnings; Special_Items: operating income (CRSP/Compustat item OPEPSQ) less GAAP_Earnings; Other_Exclusions: Total_Exclusions less Special_Items; a positive value of Total_Exclusions, Special_Items, and/or Other_Exclusions indicates an income-decreasing expense was excluded from non-GAAP earnings; Growth: incremental sales revenue (CRSP/Compustat item SALEQ) over the same quarter in the prior year, on a per share basis; Size: natural logarithm of total assets (CRSP/Compustat item ATQ) corresponding to quarter q; Loss: an indicator variable equal to one if GAAP_Earnings for the quarter is less than zero, and zero otherwise; Earnings_Volatility: standard deviation of return on assets (ROA) over preceding eight quarters (CRSP/Compustat item NIQ divided by CRSP/Compustat item ATQ); Book_to_Market_Assets: book value of equity (CRSP/Compustat item CEQQ) divided by the book value of debt (CRSP/Compustat item DLCQ plus CRSP/Compustat item DLTTQ) plus market value of equity (CRSP/Compustat item PRCCQ multiplied by CRSP/Compustat item CSHOQ); MEF (Meet or Exceed Analysts' Forecasts): is a dependent indicator variable equal to one if the current quarter $q$ of earnings surprise (i.e. Non_GAAP_Earnings less median IBES actual earnings [IBES item MEDEST] as earnings benchmarks) is greater than or equal to zero, and zero otherwise; 3_day_MAR (Market-Adjusted Return): the sum of difference between firm's valueweighted return, inclusive of dividends and other distributions, from one day before to one day after the IBES earnings announcement date, less the return on the value-weighted market portfolio; 3_day_CAR (Cumulative Abnormal Residuals): the aggregated abnormals for days $1 . .+1$ around the announcement, calculated from a market model regression estimated over trading days $-150 . .-20$ in relation to the announcement; 3_day_RAW (Raw Return): the aggregated raw return, for day -1 to day +1 around the announcement; Surprise: a firm's earnings surprise (Non_GAAP_Earnings less the consensus median earnings forecast [IBES item MEDEST]) divided by firm's market price (CRSP/Compustat item PRCCQ).

Note (1): A comparison of GAAP earnings from Compustat and IBES reveals that the Compustat GAAP earnings have much more extremes in the tails as compared to IBES data. However, the Compustat data is much more complete, and so Compustat GAAP earnings are used in order to maximise the sample size Comparison of the two distributions (Compustat GAAP earnings and IBES GAAP earnings) indicates that the distributions vary only in the extremes; these differences are removed by the winsorization process. Thus, GAAP Earnings is the Compustat GAAP earnings number. 
Table 2: Pairwise correlations

\begin{tabular}{|c|c|c|c|c|c|c|c|c|c|c|c|c|c|c|c|c|}
\hline $\begin{array}{l}\text { Panel A: } \\
\text { Regulation G. }\end{array}$ & $\begin{array}{l}\text { SUM_FutOp } \\
\text { Earn }\end{array}$ & $\begin{array}{l}\text { Future4 } \\
\text { car3 }\end{array}$ & $\begin{array}{l}\text { Future1 } \\
\text { car3 }\end{array}$ & $\begin{array}{l}\text { GAAP- } \\
\text { Earnings }\end{array}$ & $\begin{array}{l}\text { Non_GAAP_ } \\
\text { Earnings }\end{array}$ & $\begin{array}{l}\text { Total } \\
\text { Exclusions }\end{array}$ & $\begin{array}{l}\text { Special_ } \\
\text { Items }\end{array}$ & $\begin{array}{l}\text { Other } \\
\text { Exclusions }\end{array}$ & Growth & Size & Loss & $\begin{array}{l}\text { Earnings_ } \\
\text { Volatility }\end{array}$ & $\begin{array}{l}\text { Book_to_ } \\
\text { Market_ } \\
\text { Assets }\end{array}$ & MEF & $\begin{array}{l}\text { 3_day } \\
\text { CAR }\end{array}$ & Surprise \\
\hline SUM_FutOpEarn & 1.0000 & & & & & & & & & & & & & & & \\
\hline Future 4car3 & $0.0478^{* * *}$ & 1.0000 & & & & & & & & & & & & & & \\
\hline Future1car3 & $0.0986^{* * *}$ & $0.0122^{* * *}$ & 1.0000 & & & & & & & & & & & & & \\
\hline GAAP_Earnings & $0.7631^{* * *}$ & $0.0296^{* * *}$ & $0.0186^{* * *}$ & 1.0000 & & & & & & & & & & & & \\
\hline Non_GAAP_Earnings & $0.7899^{* * *}$ & $0.0270^{* * *}$ & $0.0169^{* * *}$ & $0.8718^{* * *}$ & 1.0000 & & & & & & & & & & & \\
\hline Total_Exclusions & $-0.3322^{* * *}$ & $-0.0184^{* * *}$ & $-0.0115^{* * *}$ & $-0.6798^{* * *}$ & $-0.2334^{* * *}$ & 1.0000 & & & & & & & & & & \\
\hline Special_Items & $-0.0829^{* * *}$ & -0.0012 & 0.0028 & $-0.2873^{* * *}$ & $-0.1144^{* * *}$ & $0.3992^{* * *}$ & 1.0000 & & & & & & & & & \\
\hline Other_Exclusions & $-0.0782_{* * * *}^{* * *}$ & $-0.0080^{* *}$ & $-0.0089^{* *}$ & $-0.0322^{* * *}$ & 0.0060 & $0.0729^{* * * *}$ & $-0.8853^{* * * *}$ & 1.0000 & & & & & & & & \\
\hline Growth & $0.2302^{* * *}$ & -0.0032 & 0.0052 & $0.2609^{* * *}$ & $0.2373^{* * *}$ & $-0.1626^{* * *}$ & $-0.0494^{* * *}$ & $-0.0288^{* * *}$ & 1.0000 & & & & & & & \\
\hline Size & $0.2257^{* * * *}$ & $0.0244_{* * * *}^{* * *}$ & $0.0238^{* * *}$ & $0.2297^{* * *}$ & $0.2445_{* * * *}^{* * *}$ & $-0.0900^{* * * *}$ & $-0.0367^{* * *}$ & -0.0057 & $-0.0768^{* * * *}$ & 1.0000 & & & & & & \\
\hline Loss & $-0.5636^{* * *}$ & $-0.0278^{* * *}$ & $-0.0125^{* * *}$ & $-0.6937^{* * *}$ & $-0.6143^{* * *}$ & $0.4572^{* * *}$ & $0.1599^{* * *}$ & $0.0580^{* * *}$ & $-0.2023^{* * *}$ & $-0.2688^{* * *}$ & 1.0000 & & & & & \\
\hline Earnings_Volatility & $-0.3330^{* * *}$ & $-0.0241^{* * *}$ & $-0.0241^{* * *}$ & $-0.3575^{* * *}$ & $-0.3419^{* * *}$ & $0.1978^{* * *}$ & $0.0601^{* * *}$ & $0.0349^{* * *}$ & $-0.0240^{* * *}$ & $-0.3583^{* * *}$ & $0.3637^{* * *}$ & 1.0000 & & & & \\
\hline Book_to_Market_Assets & $-0.1505^{* * *}$ & -0.0042 & 0.0039 & $-0.1193^{* * *}$ & $-0.0904^{* * *}$ & $0.1015^{* * *}$ & $0.0502^{* * *}$ & -0.0031 & $-0.1833^{* * *}$ & $-0.1635^{* * *}$ & $0.1337^{* * *}$ & $-0.0113^{* * *}$ & 1.0000 & & & \\
\hline MEF & $0.1204^{* * *}$ & 0.0050 & $-0.0137^{* * *}$ & $0.1483^{* * *}$ & $0.1541^{* * *}$ & $-0.0638^{* * *}$ & $-0.0243^{* * *}$ & -0.0060 & $0.1598^{* * *}$ & $0.0482^{* * *}$ & $-0.1487^{* * *}$ & 0.0009 & $-0.0692^{* * *}$ & 1.0000 & & \\
\hline 3_day_CAR & $0.0971^{* * *}$ & $0.0152^{* * *}$ & $-0.0127^{* * *}$ & $0.0907^{* * *}$ & $0.0801^{* * *}$ & $-0.0601^{* * *}$ & $-0.0125^{* * *}$ & $-0.0169^{* * *}$ & $0.0680^{* * *}$ & $0.0292^{* * *}$ & $-0.0827^{* * *}$ & $-0.0282^{* * *}$ & $0.0335^{* * *}$ & $0.2193^{* * *}$ & 1.0000 & \\
\hline Surprise & $0.1251^{* * *}$ & $-0.0070^{*}$ & $-0.0245^{* * *}$ & $0.2193^{* * *}$ & $0.2488^{* * *}$ & $-0.0629^{* * *}$ & $-0.0675^{* * *}$ & $0.0415^{* * *}$ & $0.1522^{* * *}$ & $0.0517^{* * *}$ & $-0.2489^{* * *}$ & $-0.0159^{* * *}$ & $-0.0780^{* * *}$ & $0.4768^{* * *}$ & $0.1557^{* * *}$ & 1.0000 \\
\hline $\begin{array}{l}\text { Panel B: } \\
\text { C\&DI }\end{array}$ & $\begin{array}{l}\text { SUM_FutOp } \\
\text { Earn }\end{array}$ & $\begin{array}{l}\text { Future4 } \\
\text { car3 }\end{array}$ & $\begin{array}{l}\text { Future1 } \\
\text { car3 }\end{array}$ & $\begin{array}{l}\text { GAAP } \\
\text { Earnings }\end{array}$ & $\begin{array}{l}\text { Non_GAAP } \\
\text { Earnings }\end{array}$ & $\begin{array}{l}\text { Total } \\
\text { Exclusions }\end{array}$ & $\begin{array}{l}\text { Special_ } \\
\text { Items }\end{array}$ & $\begin{array}{l}\text { Other } \\
\text { Exclusions }\end{array}$ & Growth & Size & Loss & $\begin{array}{l}\text { Earnings_ } \\
\text { Volatility }\end{array}$ & $\begin{array}{l}\text { Book_to_ } \\
\text { Market_- } \\
\text { Assets }\end{array}$ & MEF & $\begin{array}{l}\text { 3_day } \\
\text { CAR }\end{array}$ & Surprise \\
\hline SUM_FutOpEarn & 1.0000 & & & & & & & & & & & & & & & \\
\hline Future4car3 & $0.0492^{* * *}$ & 1.0000 & & & & & & & & & & & & & & \\
\hline Future1car3 & $0.1034^{* * *}$ & $0.0156^{* * *}$ & 1.0000 & & & & & & & & & & & & & \\
\hline GAAP_Earnings & $0.7321^{* * *}$ & $0.0188^{* * *}$ & $0.0064^{*}$ & 1.0000 & & & & & & & & & & & & \\
\hline Non_GAAP_Earnings & $0.7909^{* * *}$ & $0.0275^{* * *}$ & $0.0168^{* * *}$ & $0.8571^{* * *}$ & 1.0000 & & & & & & & & & & & \\
\hline Total_Exclusions & $-0.2416^{* * *}$ & 0.0042 & $0.0122^{* * *}$ & $-0.6568^{* *}$ & $-0.1746^{* * *}$ & 1.0000 & & & & & & & & & & \\
\hline Special_Items & $-0.0539^{* * *}$ & $0.0146^{* * *}$ & $0.0198^{* * *}$ & $-0.3708^{* * *}$ & $-0.1055^{* * *}$ & $0.5543^{* * *}$ & 1.0000 & & & & & & & & & \\
\hline Other_Exclusions & $-0.1296^{* * *}$ & $-0.0142^{* * *}$ & $-0.0138^{* * *}$ & $-0.0856^{* * *}$ & $-0.0144^{* * *}$ & $0.1425^{* * *}$ & $-0.7448^{* * *}$ & 1.0000 & & & & & & & & \\
\hline Growth & $0.1926^{* * *}$ & -0.0054 & -0.0008 & $0.2467^{* * *}$ & $0.2218^{* * *}$ & $-0.1470^{* * *}$ & $-0.0729^{* * *}$ & $-0.0311^{* * *}$ & 1.0000 & & & & & & & \\
\hline Size & $0.2465^{* * *}$ & $0.0155^{* * *}$ & $0.0114^{* * *}$ & $0.2389^{* * *}$ & $0.2455^{* * *}$ & $-0.0973^{* * *}$ & $-0.0336^{* * *}$ & $-0.0381^{* * *}$ & $-0.0862^{* * *}$ & 1.0000 & & & & & & \\
\hline Loss & $-0.5169^{* * *}$ & $-0.0172^{* * *}$ & 0.0015 & $-0.6739^{* * *}$ & $-0.5886^{* * *}$ & $0.4267^{* * *}$ & $0.2057^{* * *}$ & $0.0975^{* * *}$ & $-0.1997^{* * *}$ & $-0.2615^{* * *}$ & 1.0000 & & & & & \\
\hline Earnings_Volatility & $-0.3146^{* * *}$ & $-0.0180^{* * *}$ & $-0.0118^{* * *}$ & $-0.3225^{* * *}$ & $-0.3171^{* * *}$ & $0.1522^{* * *}$ & $0.0276^{* * *}$ & $0.0892^{* * *}$ & $-0.0367^{* * *}$ & $-0.3532^{* * *}$ & $0.3161^{* * *}$ & 1.0000 & & & & \\
\hline Book_to_Market_Assets & $-0.0963^{* * *}$ & 0.0014 & -0.0034 & $-0.0596^{* * *}$ & $-0.0433^{* * *}$ & $0.0505^{* * *}$ & $0.0473^{* * *}$ & $-0.0157^{* * *}$ & $-0.1896^{* * *}$ & $-0.0734^{* * *}$ & $0.0750^{* * *}$ & $-0.0478^{* * *}$ & & & & \\
\hline $\mathrm{MEF}^{-}$ & $0.1379^{* * *}$ & 0.0038 & $-0.0104^{* * *}$ & $0.1733^{* * *}$ & $0.2067^{* * *}$ & $-0.0288^{* * *}$ & $-0.0404^{* * *}$ & $0.0250^{* * *}$ & $0.1290^{* * *}$ & $0.0634^{* * *}$ & $-0.1749^{* * *}$ & -0.0014 & $-0.0464^{* * *}$ & 1.0000 & & \\
\hline 3_day_CAR & $0.0971^{* * *}$ & $0.0100^{* * *}$ & $-0.0199^{* * *}$ & $0.1010^{* * *}$ & $0.0984^{* * *}$ & $-0.0490^{* * *}$ & $-0.0130^{* * *}$ & $-0.0238^{* * *}$ & $0.0781^{* * *}$ & $0.0191^{* * *}$ & $-0.0972^{* * *}$ & $-0.0078^{* *}$ & $0.0200^{* * *}$ & $0.2634^{* * *}$ & 1.0000 & \\
\hline Surprise & $0.0969^{* * *}$ & -0.0059 & $-0.0278^{* * *}$ & $0.2133^{* * *}$ & $0.2647^{* * *}$ & $-0.0202^{* * *}$ & $-0.0987^{* * *}$ & $0.1012^{* * *}$ & $0.1326^{* * *}$ & $0.0217^{* * *}$ & $-0.2414^{* * *}$ & $0.0167^{* * *}$ & $-0.0291^{* * *}$ & $0.5355^{* * *}$ & $0.2065^{* * *}$ & 1.0000 \\
\hline
\end{tabular}

Variables are defined in Table 1. There are a maximum of 84,062 firm-quarters for each variable for Regulation G sample and 68,210 firm-quarters for C\&Dls.

$*, * *$, and ${ }^{* * *}$ represent significance levels at $10 \%, 5 \%$, and $1 \%$, respectively (two-tailed test). 
Table 3: Future operating earnings on exclusions and control variables (H1)

Dependent Variable: SUM FutOpEarn

\begin{tabular}{|c|c|c|c|c|}
\hline & \multicolumn{2}{|c|}{$\underline{\text { Regulation G }}$} & \multicolumn{2}{|c|}{ C\&DIs } \\
\hline & $\begin{array}{l}\text { Coefficient } \\
\text { (std error.) }\end{array}$ & $\begin{array}{l}\text { Coefficient } \\
\text { (std error.) }\end{array}$ & $\begin{array}{l}\text { Coefficient } \\
\text { (std error.) }\end{array}$ & $\begin{array}{l}\text { Coefficient } \\
\text { (std error.) }\end{array}$ \\
\hline \multirow[t]{2}{*}{ Intercept } & $-0.0503^{* * *}$ & $-0.0391^{* * *}$ & $-0.0691^{* * *}$ & $-0.0582^{* * *}$ \\
\hline & (0.002) & (0.002) & (0.002) & $(0.002)$ \\
\hline \multirow[t]{2}{*}{ Non_GAAP_Earnings } & $0.0195^{* * *}$ & $0.0188^{* * *}$ & $0.0203^{* * *}$ & $0.0197^{* * *}$ \\
\hline & $(0.000)$ & $(0.000)$ & $(0.000)$ & $(0.000)$ \\
\hline \multirow[t]{2}{*}{ Total_Exclusions } & $-0.0086^{* * *}$ & & $-0.0065^{* * *}$ & \\
\hline & $(0.000)$ & & $(0.000)$ & \\
\hline \multirow[t]{2}{*}{ Special_Items } & & $0.0006^{* * *}$ & & $0.0012^{* * *}$ \\
\hline & & $(0.000)$ & & $(0.000)$ \\
\hline \multirow[t]{2}{*}{ Other_Exclusions } & & $-0.0091^{* * *}$ & & $-0.0076^{* * *}$ \\
\hline & & $(0.000)$ & & $(0.000)$ \\
\hline \multirow[t]{2}{*}{ POST } & $-0.0066^{* * *}$ & $-0.0059^{* * *}$ & $-0.0051^{* * *}$ & $-0.0053^{* * *}$ \\
\hline & $(0.001)$ & $(0.001)$ & $(0.001)$ & $(0.002)$ \\
\hline \multirow[t]{2}{*}{ Total_Exclusions $\times$ POST } & $0.0013^{* * *}$ & & $0.0011^{* * *}$ & \\
\hline & $(0.000)$ & & $(0.000)$ & \\
\hline \multirow[t]{2}{*}{ Special_Items $\times$ POST } & & 0.0003 & & $-0.0003^{* *}$ \\
\hline & & $(0.000)$ & & $(0.000)$ \\
\hline \multirow[t]{2}{*}{ Other_Exclusions $\times$ POST } & & $0.0012^{* * *}$ & & $0.0013^{* * *}$ \\
\hline & & $(0.000)$ & & $(0.000)$ \\
\hline \multirow[t]{2}{*}{ Growth } & $0.0013^{* * *}$ & $0.0012^{* * *}$ & $0.0012^{* * *}$ & $0.0011^{* * *}$ \\
\hline & $(0.000)$ & $(0.000)$ & $(0.000)$ & $(0.000)$ \\
\hline \multirow[t]{2}{*}{ Size } & $0.0052^{* * *}$ & $0.0045^{* * *}$ & $0.0057^{* * *}$ & $0.0051^{* * *}$ \\
\hline & $(0.000)$ & $(0.000)$ & $(0.000)$ & $(0.000)$ \\
\hline \multirow[t]{2}{*}{ Loss } & $-0.0312^{* * *}$ & $-0.0428^{* * *}$ & $-0.0219^{* * *}$ & $-0.0307^{* * *}$ \\
\hline & $(0.001)$ & $(0.001)$ & $(0.001)$ & $(0.001)$ \\
\hline \multirow[t]{2}{*}{ Earnings_Volatility } & $-0.0031^{* * *}$ & $-0.0031^{* * *}$ & $-0.0029^{* * *}$ & $-0.0030^{* * *}$ \\
\hline & $(0.000)$ & $(0.000)$ & $(0.000)$ & $(0.000)$ \\
\hline \multirow[t]{2}{*}{ Book_to_Market_Assets } & $0.0004^{* * *}$ & $0.0004^{* * *}$ & $0.0011^{* * *}$ & $0.0010^{* * *}$ \\
\hline & $(0.000)$ & $(0.000)$ & $(0.000)$ & $(0.000)$ \\
\hline Adjusted- $R^{2}$ & 0.492 & 0.501 & 0.467 & 0.479 \\
\hline Number of Firm-Quarters & 69,800 & 69,800 & 67,874 & 67,874 \\
\hline
\end{tabular}

POST: an indicator variable that equals one if the observation falls after q1 2003 for Regulation G sample, as well as after $q 12010$ for C\&DIs sample, and zero otherwise. Other variables are defined in Table 1. All continuous variables are winsorized at the top and bottom $2 \%$. Robust standard errors are reported below the coefficients. ${ }^{*}, * *$, and ${ }^{* * *}$ represent significance levels at $10 \%, 5 \%$, and $1 \%$, respectively (two-tailed test). 
Table 4: 3-day CAR in q+4 on exclusions and control variables (H1)

Dependent Variable: Future4CAR3

\begin{tabular}{|c|c|c|c|c|}
\hline & \multicolumn{2}{|c|}{$\underline{\text { Regulation G }}$} & \multicolumn{2}{|c|}{ C\&DIs } \\
\hline & $\begin{array}{l}\text { Coefficient } \\
\text { (std error.) }\end{array}$ & $\begin{array}{l}\text { Coefficient } \\
\text { (std error.) }\end{array}$ & $\begin{array}{l}\text { Coefficient } \\
\text { (std error.) }\end{array}$ & $\begin{array}{l}\text { Coefficient } \\
\text { (std error.) }\end{array}$ \\
\hline \multirow[t]{2}{*}{ Intercept } & 0.0016 & 0.0023 & 0.0025 & 0.0028 \\
\hline & $(0.002)$ & $(0.002)$ & $(0.002)$ & $(0.002)$ \\
\hline \multirow[t]{2}{*}{ Non_GAAP_Earnings } & -0.0001 & -0.0002 & 0.0002 & 0.0001 \\
\hline & $(0.000)$ & $(0.000)$ & $(0.000)$ & $(0.000)$ \\
\hline \multirow[t]{2}{*}{ Total_Exclusions } & $-0.0004^{* *}$ & & $-0.0003^{*}$ & \\
\hline & $(0.000)$ & & $(0.000)$ & \\
\hline \multirow[t]{2}{*}{ Special_Items } & & 0.0002 & & $0.0004^{* * *}$ \\
\hline & & $(0.000)$ & & $(0.000)$ \\
\hline \multirow[t]{2}{*}{ Other_Exclusions } & & $-0.0004^{* *}$ & & $-0.0004^{* * *}$ \\
\hline & & $(0.000)$ & & $(0.000)$ \\
\hline \multirow[t]{2}{*}{ POST } & 0.0008 & 0.0010 & $-0.0045^{* * *}$ & $-0.0043^{* * *}$ \\
\hline & $(0.001)$ & $(0.001)$ & $(0.001)$ & $(0.001)$ \\
\hline \multirow[t]{2}{*}{ Total_Exclusions $\times$ POST } & -0.0003 & & $0.0006^{* * *}$ & \\
\hline & $(0.000)$ & & $(0.000)$ & \\
\hline \multirow[t]{2}{*}{ Special_Items $\times$ POST } & & -0.0001 & & 0.0001 \\
\hline & & $(0.000)$ & & $(0.000)$ \\
\hline \multirow[t]{2}{*}{ Other_Exclusions $\times$ POST } & & -0.0002 & & $0.0005^{* *}$ \\
\hline & & $(0.000)$ & & $(0.000)$ \\
\hline \multirow[t]{2}{*}{ Growth } & -0.0001 & -0.0001 & -0.0001 & -0.0001 \\
\hline & $(0.000)$ & $(0.000)$ & $(0.000)$ & $(0.000)$ \\
\hline \multirow[t]{2}{*}{ Size } & $0.0006^{* * *}$ & $0.0005^{* * *}$ & $0.0002^{* *}$ & 0.0001 \\
\hline & $(0.000)$ & $(0.000)$ & $(0.000)$ & $(0.000)$ \\
\hline \multirow[t]{2}{*}{ Loss } & $-0.0028^{* *}$ & $-0.0042^{* * *}$ & -0.0014 & $-0.0020^{*}$ \\
\hline & $(0.001)$ & $(0.001)$ & $(0.001)$ & $(0.001)$ \\
\hline \multirow[t]{2}{*}{ Earnings_Volatility } & -0.0000 & -0.0000 & $-0.0003^{* *}$ & $-0.0003^{* *}$ \\
\hline & $(0.000)$ & $(0.000)$ & $(0.000)$ & $(0.000)$ \\
\hline \multirow[t]{2}{*}{ Book_to_Market_Assets } & 0.0001 & 0.0001 & 0.0001 & 0.0001 \\
\hline & $(0.000)$ & $(0.000)$ & $(0.000)$ & $(0.000)$ \\
\hline Adjusted- $R^{2}$ & 0.002 & 0.002 & 0.001 & 0.001 \\
\hline Number of Firm-Quarters & 68,575 & 68,575 & 66,541 & 66,541 \\
\hline
\end{tabular}

POST: an indicator variable that equals one if the observation falls after $q 12003$ for Regulation $\mathrm{G}$ sample, as well as after $q 12010$ for C\&DIs, and zero otherwise. Other variables are defined in Table 1. All continuous variables are winsorized at the top and bottom $2 \%$. Robust standard errors are reported below the coefficients. ${ }^{*}, * *$, and ${ }^{* * *}$ represent significance levels at $10 \%, 5 \%$, and $1 \%$, respectively (two-tailed test). 
Table 5: 3-day CAR in q+1 on exclusions and control variables (H1)

Dependent Variable: Future1CAR3

\begin{tabular}{|c|c|c|c|c|}
\hline & \multicolumn{2}{|c|}{ Regulation G } & \multicolumn{2}{|c|}{ C\&DIs } \\
\hline & $\begin{array}{l}\text { Coefficient } \\
\text { (std error.) }\end{array}$ & $\begin{array}{l}\text { Coefficient } \\
\text { (std error.) }\end{array}$ & $\begin{array}{l}\text { Coefficient } \\
\text { (std error.) }\end{array}$ & $\begin{array}{l}\text { Coefficient } \\
\text { (std error.) }\end{array}$ \\
\hline \multirow[t]{2}{*}{ Intercept } & 0.0007 & $0.0032^{*}$ & 0.0016 & 0.0024 \\
\hline & $(0.002)$ & $(0.002)$ & $(0.002)$ & $(0.002)$ \\
\hline \multirow[t]{2}{*}{ Non_GAAP_Earnings } & $-0.0004^{* * *}$ & $-0.0005^{* * *}$ & $-0.0003^{*}$ & $-0.0003^{* *}$ \\
\hline & $(0.000)$ & $(0.000)$ & $(0.000)$ & $(0.000)$ \\
\hline \multirow[t]{2}{*}{ Total_Exclusions } & $-0.0007^{* * *}$ & & -0.0000 & \\
\hline & $(0.000)$ & & $(0.000)$ & \\
\hline \multirow[t]{2}{*}{ Special_Items } & & $0.0004^{* * *}$ & & $0.0007^{* * *}$ \\
\hline & & $(0.000)$ & & $(0.000)$ \\
\hline \multirow[t]{2}{*}{ Other_Exclusions } & & $-0.0011^{* * *}$ & & $-0.0004^{* * *}$ \\
\hline & & $(0.000)$ & & $(0.000)$ \\
\hline \multirow[t]{2}{*}{ POST } & $-0.0023^{*}$ & $-0.0028^{*}$ & $-0.0023^{*}$ & $-0.0027^{*}$ \\
\hline & $(0.001)$ & $(0.001)$ & $(0.001)$ & $(0.001)$ \\
\hline \multirow[t]{2}{*}{ Total_Exclusions $\times$ POST } & 0.0002 & & 0.0002 & \\
\hline & $(0.000)$ & & $(0.000)$ & \\
\hline \multirow[t]{2}{*}{ Special_Items $\times$ POST } & & -0.0001 & & $-0.0003^{*}$ \\
\hline & & $(0.000)$ & & $(0.000)$ \\
\hline \multirow[t]{2}{*}{ Other_Exclusions $\times$ POST } & & 0.0004 & & $0.0005^{* *}$ \\
\hline & & $(0.000)$ & & $(0.000)$ \\
\hline \multirow[t]{2}{*}{ Growth } & $0.0004^{* * *}$ & $0.0004^{* * *}$ & $0.0002^{* *}$ & $0.0002^{*}$ \\
\hline & $(0.000)$ & $(0.000)$ & $(0.000)$ & $(0.000)$ \\
\hline \multirow[t]{2}{*}{ Size } & $0.0007^{* * *}$ & $0.0006^{* * *}$ & $0.0003^{* * *}$ & 0.0002 \\
\hline & $(0.000)$ & $(0.000)$ & $(0.000)$ & $(0.000)$ \\
\hline \multirow[t]{2}{*}{ Loss } & -0.0000 & -0.0011 & 0.0003 & -0.0004 \\
\hline & $(0.001)$ & $(0.001)$ & $(0.001)$ & $(0.001)$ \\
\hline \multirow[t]{2}{*}{ Earnings_Volatility } & -0.0002 & -0.0002 & -0.0001 & -0.0002 \\
\hline & $(0.000)$ & $(0.000)$ & $(0.000)$ & $(0.000)$ \\
\hline \multirow[t]{2}{*}{ Book_to_Market_Assets } & $0.0004^{* * *}$ & $0.0004^{* * *}$ & -0.0000 & -0.0001 \\
\hline & $(0.000)$ & $(0.000)$ & $(0.000)$ & $(0.000)$ \\
\hline Adjusted- $R^{2}$ & 0.002 & 0.002 & 0.000 & 0.001 \\
\hline Number of Firm-Quarters & 69,593 & 69,593 & 67,632 & 67,632 \\
\hline
\end{tabular}

POST: an indicator variable that equals one if the observation falls after $q 12003$ for Regulation $\mathrm{G}$ sample, as well as after $q 12010$ for C\&DIs, and zero otherwise. Other variables are defined in Table 1. All continuous variables are winsorized at the top and bottom $2 \%$. Robust standard errors are reported below the coefficients. ${ }^{*}, * *$, and ${ }^{* * *}$ represent significance levels at $10 \%, 5 \%$, and $1 \%$, respectively (two-tailed test). 
Table 6: Probit regressions of 'meet or exceed analysts' forecasts' (MEF) on exclusion variables (H2) Dependent Variable: MEF

\begin{tabular}{|c|c|c|c|c|}
\hline & \multicolumn{2}{|c|}{$\underline{\text { Regulation G }}$} & \multicolumn{2}{|c|}{ C\&DIs } \\
\hline & $\begin{array}{l}\text { Coefficient } \\
\text { (std error.) }\end{array}$ & $\begin{array}{l}\text { Coefficient } \\
\text { (std error.) }\end{array}$ & $\begin{array}{l}\text { Coefficient } \\
\text { (std error.) }\end{array}$ & $\begin{array}{l}\text { Coefficient } \\
\text { (std error.) }\end{array}$ \\
\hline Intercept & $0.3751^{* * *}$ & $0.3645^{* * *}$ & $0.7569^{* * *}$ & $0.7329^{* * *}$ \\
\hline & $(4.1300)$ & (3.9700) & $(10.0400)$ & $(9.3800)$ \\
\hline Positive_Total_Exclusions & $\begin{array}{l}3.7230^{* * *} \\
(5.5000)\end{array}$ & & $\begin{array}{l}2.1068^{* * *} \\
(2.9400)\end{array}$ & \\
\hline Positive_Special_Items & & $\begin{array}{l}3.8188^{* * *} \\
(5.0100)\end{array}$ & & $\begin{array}{l}2.4305^{* * *} \\
(3.3400)\end{array}$ \\
\hline Positive_Other_Exclusions & & $\begin{array}{l}3.8577^{* * *} \\
(3.7000)\end{array}$ & & $\begin{array}{l}4.4667^{* * *} \\
(5.6500)\end{array}$ \\
\hline Sox & $\begin{array}{c}-0.2257^{* * *} \\
(-31.1900)\end{array}$ & $\begin{array}{c}-0.2240^{* * *} \\
(-29.2600)\end{array}$ & & \\
\hline POST & $\begin{array}{c}0.0089 \\
(0.3100)\end{array}$ & $\begin{array}{c}0.0064 \\
(0.2100)\end{array}$ & $\begin{array}{c}0.0313 \\
(0.4500)\end{array}$ & $\begin{array}{c}0.0281 \\
(0.4100)\end{array}$ \\
\hline Positive_Total_Exclusions $\times$ SOX & $\begin{array}{c}1.0462^{* * *} \\
(10.4500)\end{array}$ & & & \\
\hline Positive_Special_Items $\times$ SOX & & $\begin{array}{c}1.6222^{* * *} \\
(16.4000)\end{array}$ & & \\
\hline Positive_Other_Exclusions $\times$ SOX & & $\begin{array}{l}-0.3059^{* *} \\
(-2.0500)\end{array}$ & & \\
\hline Positive_Total_Exclusions $\times$ POST & $\begin{array}{c}-0.5639^{*} \\
(-1.6900)\end{array}$ & & $\begin{array}{l}1.8760^{* * *} \\
(3.1100)\end{array}$ & \\
\hline Positive_Special_Items $\times$ POST & & $\begin{array}{c}-0.8765^{* * *} \\
(-3.0500)\end{array}$ & & $\begin{array}{c}0.8792^{*} \\
(1.9400)\end{array}$ \\
\hline Positive_Other_Exclusions $\times$ POST & & $\begin{array}{c}0.2441 \\
(0.5300)\end{array}$ & & $\begin{array}{l}2.8929^{* * *} \\
(3.2000)\end{array}$ \\
\hline Growth & $\begin{array}{l}3.2986^{* * *} \\
(13.6600)\end{array}$ & $\begin{array}{c}3.2885^{* * *} \\
(13.6300)\end{array}$ & $\begin{array}{l}2.7736^{* * *} \\
(4.2700)\end{array}$ & $\begin{array}{l}2.7396^{* * *} \\
(4.1600)\end{array}$ \\
\hline Size & $\begin{array}{l}0.0001 \\
(0.0100)\end{array}$ & $\begin{array}{c}0.0015 \\
(0.1900)\end{array}$ & $\begin{array}{c}-0.0111 \\
(-1.4100)\end{array}$ & $\begin{array}{l}-0.0094 \\
(-1.1400)\end{array}$ \\
\hline Loss & $\begin{array}{l}-0.6249^{* * *} \\
(-19.1100)\end{array}$ & $\begin{array}{c}-0.6311^{* * *} \\
(-18.4000)\end{array}$ & $\begin{array}{c}-0.7031^{* * *} \\
(-32.2600)\end{array}$ & $\begin{array}{c}-0.7151^{* * *} \\
(-33.3100)\end{array}$ \\
\hline Earnings_Volatility & $\begin{array}{l}2.1839^{* * *} \\
(5.4700)\end{array}$ & $\begin{array}{l}2.1080^{* * *} \\
(5.0400)\end{array}$ & $\begin{array}{c}1.3592^{*} \\
(1.6800)\end{array}$ & $\begin{array}{c}1.0863 \\
(1.3700)\end{array}$ \\
\hline Book_to_Market_Assets & $\begin{array}{l}-0.0829 \\
(-1.2100)\end{array}$ & $\begin{array}{l}-0.0709 \\
(-1.0500)\end{array}$ & $\begin{array}{l}-0.1153^{*} \\
(-1.7900)\end{array}$ & $\begin{array}{l}-0.0937 \\
(-1.4700)\end{array}$ \\
\hline Pseudo- $R^{2}$ & 0.0586 & 0.0597 & 0.0577 & 0.0602 \\
\hline Number of Firm-Quarters & 19,991 & 19,991 & 26,786 & 26,786 \\
\hline
\end{tabular}

Positive_Total_Exclusions: equal to the magnitude of Total_Exclusions if Total_Exclusions are greater than zero, and zero otherwise; Positive_Special_Items: equal to the magnitude of Special_Items if greater than zero, and zero otherwise; Positive_Other_Exclusions: equal to the magnitude of Other_Exclusions if greater than zero, and zero otherwise. POST: an indicator variable that equals one if the observation falls after $q 12003$ for Regulation G sample, as well as after $q 12010$ for C\&DIs, and zero otherwise. SOX is an indicator variable defined by Heflin and Hsu (2008) for quarters on or after 2002Q3. The POST variable here is equivalent to theirs. Other variables are defined in Table 1. All continuous variables are winsorized at the top and bottom $2 \%$. Robust standard errors are reported below the coefficients. ${ }^{*}, * *$, and ${ }^{* * *}$ represent significance levels at $10 \%, 5 \%$, and $1 \%$, respectively (twotailed test). 
Table 7: Market reaction to earnings announcement (H3), with NonGAAPusagexSurprisexPost interaction

Dependent Variable: 3_day_CAR

\begin{tabular}{|c|c|c|c|c|}
\hline & \multicolumn{2}{|c|}{ Regulation $\mathrm{G}$} & \multicolumn{2}{|c|}{ C\&Dis } \\
\hline & $\begin{array}{l}\text { Coefficient } \\
\text { (std error.) }\end{array}$ & $\begin{array}{l}\text { Coefficient } \\
\text { (std error.) }\end{array}$ & $\begin{array}{l}\text { Coefficient } \\
\text { (std error.) }\end{array}$ & $\begin{array}{l}\text { Coefficient } \\
\text { (std error.) }\end{array}$ \\
\hline \multirow[t]{2}{*}{ Intercept } & $-0.0159^{* * *}$ & $-0.0155^{* * *}$ & $-0.0150^{* * *}$ & $-0.0149^{* *}$ \\
\hline & $(0.002)$ & $(0.002)$ & $(0.001)$ & $(0.001)$ \\
\hline \multirow[t]{2}{*}{ Surprise } & $0.8992^{* * *}$ & $0.9046^{* * *}$ & $1.2998^{* * *}$ & $1.3137^{* *}$ \\
\hline & $(0.064)$ & $(0.064)$ & $(0.050)$ & $(0.050)$ \\
\hline \multirow[t]{2}{*}{ Positive_Total_Exclusions_i } & $-0.0035^{* * *}$ & & $-0.0040^{* * *}$ & \\
\hline & $(0.001)$ & & $(0.001)$ & \\
\hline \multirow[t]{2}{*}{ Positive_Special_Items_i } & & 0.0009 & & $0.0020^{* *}$ \\
\hline & & (0.001) & & (0.001) \\
\hline \multirow[t]{2}{*}{ Positive_Other_Exclusions_i } & & $-0.0047^{* * *}$ & & $-0.0053^{* *}$ \\
\hline & & $(0.001)$ & & $(0.001)$ \\
\hline \multirow[t]{2}{*}{ POST } & $-0.0039^{* * *}$ & $-0.0040^{* * *}$ & $-0.0017^{* *}$ & $-0.0015^{*}$ \\
\hline & $(0.001)$ & $(0.001)$ & $(0.001)$ & $(0.001)$ \\
\hline \multirow[t]{2}{*}{ Surprise $\times$ POST } & $0.3196^{* * *}$ & $0.3167^{* * *}$ & $0.2784^{* * *}$ & $0.2567^{* *}$ \\
\hline & $(0.107)$ & (0.107) & (0.098) & (0.099) \\
\hline \multirow[t]{2}{*}{ NonGAAPusage $\times$ Surprise $\times$ POST } & $0.2212^{* *}$ & $0.2358^{* *}$ & $-0.2253^{* *}$ & $-0.2191^{* *}$ \\
\hline & $(0.108)$ & $(0.108)$ & $(0.103)$ & $(0.103)$ \\
\hline \multirow[t]{2}{*}{ Positive_Total_Exclusions_i $\times$ POST } & -0.0015 & & -0.0006 & \\
\hline & $(0.002)$ & & $(0.001)$ & \\
\hline \multirow[t]{2}{*}{ Positive_Special_Items_i $\times$ POST } & & 0.0002 & & $-0.0042^{* *}$ \\
\hline & & $(0.002)$ & & $(0.001)$ \\
\hline \multirow[t]{2}{*}{ Positive_Other_Exclusions_i $\times$ POST } & & -0.0011 & & $0.0022^{*}$ \\
\hline & & $(0.002)$ & & $(0.001)$ \\
\hline \multirow[t]{2}{*}{ Growth } & $0.0016^{* * *}$ & $0.0016^{* * *}$ & $0.0016^{* * *}$ & $0.0016^{* *}$ \\
\hline & $(0.000)$ & $(0.000)$ & $(0.000)$ & $(0.000)$ \\
\hline \multirow[t]{2}{*}{ Size } & $0.0010^{* * *}$ & $0.0009^{* * *}$ & $0.0007^{* * *}$ & $0.0006^{* *}$ \\
\hline & $(0.000)$ & $(0.000)$ & $(0.000)$ & $(0.000)$ \\
\hline \multirow[t]{2}{*}{ Loss } & $-0.0045^{* * *}$ & $-0.0050^{* * *}$ & $-0.0055^{* * *}$ & $-0.0059^{* *}$ \\
\hline & $(0.001)$ & $(0.001)$ & $(0.001)$ & $(0.001)$ \\
\hline \multirow[t]{2}{*}{ Earnings_Volatility } & 0.0001 & 0.0001 & $0.0003^{* * *}$ & $0.0003^{* *}$ \\
\hline & $(0.000)$ & $(0.000)$ & $(0.000)$ & $(0.000)$ \\
\hline \multirow[t]{2}{*}{ Book_to_Market_Assets } & $0.0016^{* * *}$ & $0.0015^{* * *}$ & $0.0010^{* * *}$ & $0.0010^{* *}$ \\
\hline & $(0.000)$ & $(0.000)$ & $(0.000)$ & $(0.000)$ \\
\hline Adjusted- $R^{2}$ & 0.034 & 0.034 & 0.050 & 0.050 \\
\hline Number of Firm-Quarters & 69,800 & 69,800 & 67,874 & 67,874 \\
\hline
\end{tabular}

3_day_CAR: constructed using a market model estimated from the firm's value-weighted return (inclusive of dividends and other distributions) and the value-weighted S\&P 500 as a market portfolio from CRSP Daily Stock/Security file, from one day before to one day after the IBES earnings announcement date; Surprise: a firm's earnings surprise divided by firm's market price; NonGAAPusage is 0 if GAAP earnings are equal to "non-GAAP" announced earnings, 1 otherwise; Positive_Total_Exclusions_i: an indicator variable equal to one if Total_Exclusions are greater than zero, and zero otherwise; Positive_Special_Items_i: an indicator variable equal to one if Special_Items are greater than zero, and zero otherwise; Positive_Other_Exclusions_i: an indicator variable equal to one if Other_Exclusions are greater than zero, and zero otherwise. POST: an indicator variable that equals one if the observation falls after q1 2003 for Regulation G sample, as well as after q1 2010 for C\&DIs, and zero otherwise. Other variables are defined in Table 1. All continuous variables are winsorized at the top and bottom $2 \%$. Robust standard errors are reported below the coefficients. *, **, and ${ }^{* * *}$ represent significance levels at $10 \%, 5 \%$, and $1 \%$, respectively (two-tailed test). 